\begin{tabular}{|c|c|}
\hline 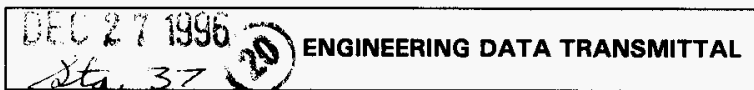 & 1. Eot 619107 \\
\hline
\end{tabular}

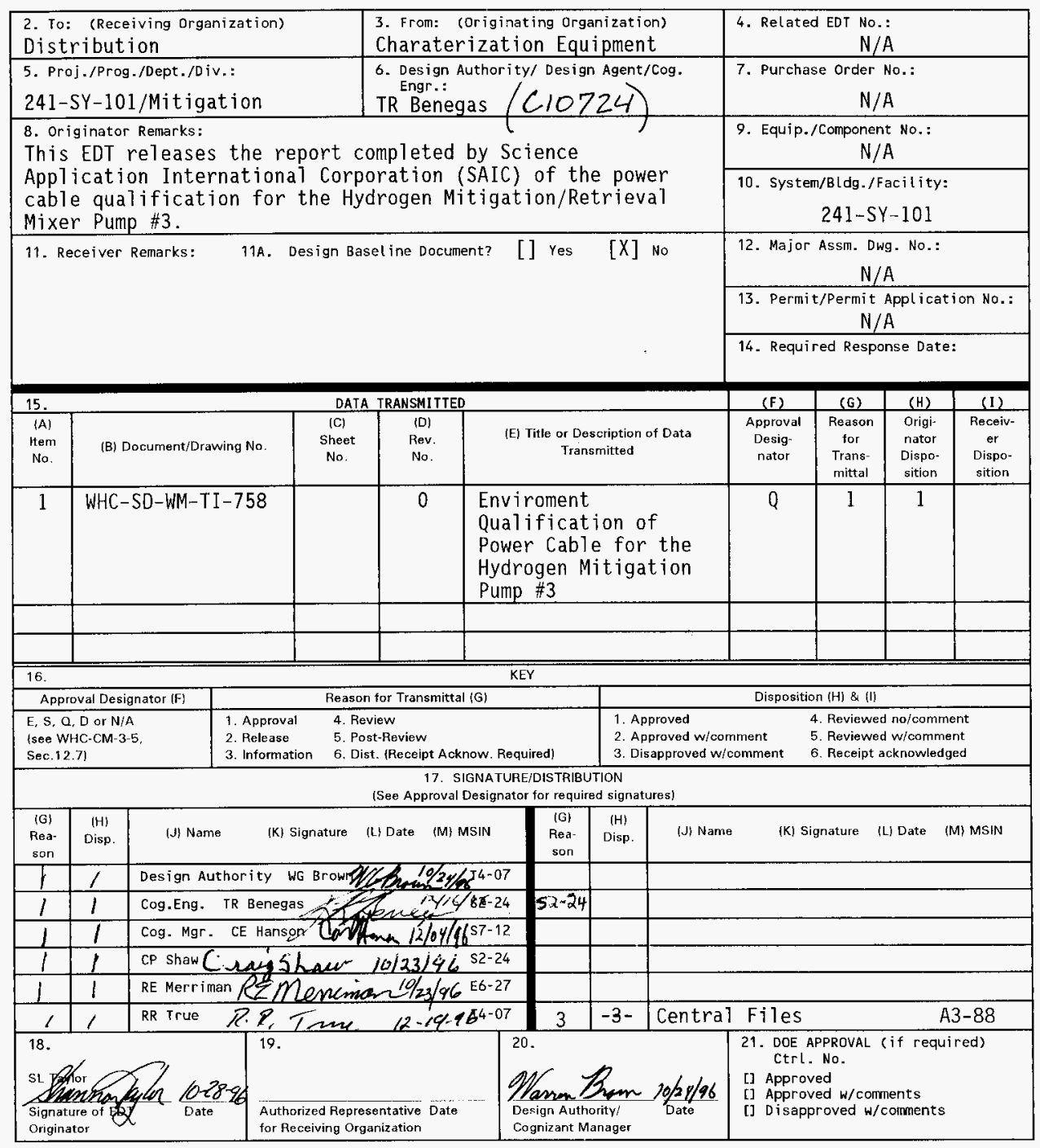

BD-7400-172-2 (05/96) GEF097 


\section{Environment Qualification of Power Cable for the Hydrogen Mitigation Pump \#3}

T. R. Benegas

SESC, Richland, WA 99352

U.S. Department of Energy Contract DE-AC06-87RL10930

EDT/ECN: 619107

UC: 2000

Org Code: 75250

Charge Code: C10724

B\&R Code: EW3120072

Total Pages: - $102-103 \mathrm{gs}$

Key Words: Mitigation, Pump \#3, Cables, HMR \#3, 241-SY-101, Qualification

Abstract: This report presents the severe environment qualification of the power cable in severe radiation and thermal conditions. This qual ification program provides Flour Daniel Hanford Company information for the use of the new cable in the mixer pump for hydrogen mitigation and retrieval purposes.

TRADEMARK DISCLAIMER. Reference herein to any specific commercial product, process, or service by trade name, trademark, manufacturer, or otherwise, does not necessarily constitute or imply its endorsement, recommendation, or favoring by the United States Government or any agency thereof or its contractors or subcontractors.

Printed in the United States of America. To obtain copies of this document, contact: WHC/BCS Document Control Services, P.O. Box 1970, Mailstop H6-08, Richland WA 99352, Phone (509) 372-2420; Fax (509) $376-4989$.
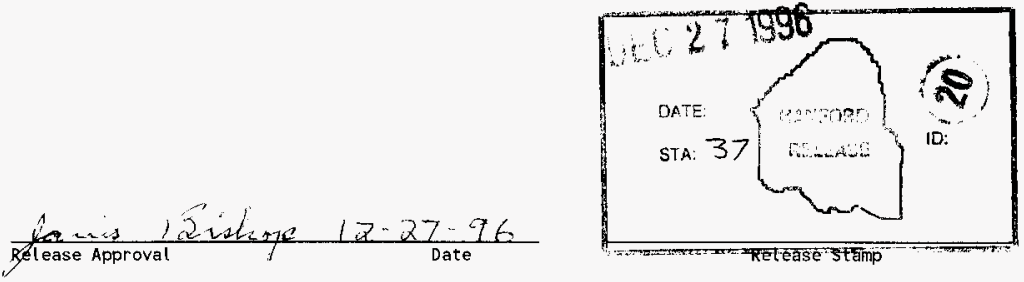


\section{Environment Qualification of Power Cable for the Hydrogen Mitigation Pump \#3}

\section{Thermal and Radiation Environment}

June 21, 1996

Prepared for:

WESTINGHOUSE HANFORD COMPANY

P. O. Box 1970

Richland, Washington 99352

Prepared by:

SCIENCE APPLICATIONS INTERNATIONAL CORPORATION 3250 Port of Benton Boulevard

Richland, Washington 99352 
WHC-SD-WM-TI-758, Rev. 0

\section{Table of Contents}

1.0 INTRODUCTION $\ldots \ldots \ldots \ldots \ldots \ldots \ldots \ldots \ldots \ldots \ldots \ldots \ldots \ldots \ldots \ldots$

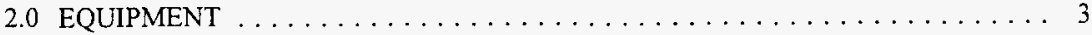

3.0 SEVERE ENVIRONMENT CONDITIONS $\ldots \ldots \ldots \ldots \ldots \ldots \ldots \ldots$

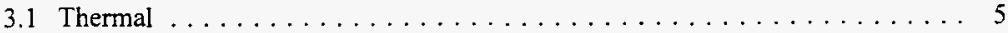

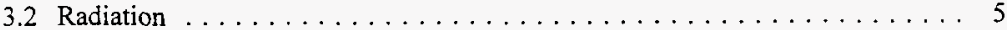

4.0 QUALIFIED LIFE TESTING $\ldots \ldots \ldots \ldots \ldots \ldots \ldots \ldots \ldots \ldots \ldots \ldots$

4.1 Thermal and Radiation Testing $\ldots \ldots \ldots \ldots \ldots \ldots \ldots \ldots \ldots \ldots \ldots \ldots \ldots \ldots \ldots$

4.2 Thermal and Radiation Test Results $\ldots \ldots \ldots \ldots \ldots \ldots \ldots$

5.0 SUMMARY $\ldots \ldots \ldots \ldots \ldots \ldots \ldots \ldots \ldots \ldots \ldots \ldots \ldots$

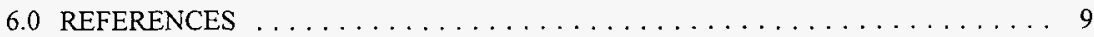

APPENDIX A - Radix Wire Company Power Cable Specifications

APPENDIX B - Environmental Qualification Test Procedure for Cable Samples

APPENDIX C - National Testing Systems, Inc.

Environmental Qualification Test Report for Cable Samples 
WHC-SD-WM-TI-758, Rev. 0

\section{List of Tables}

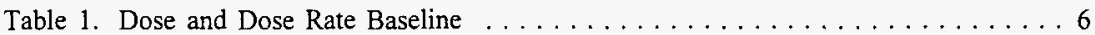


WHC-SD-WM-TI-758, Rev. 0

\subsection{INTRODUCTION}

The Hydrogen Mitigation Test Pump (Mixer Pump) was installed in Tank 241-SY-101 of the Hanford underground storage tanks in July 1993. The pump mixes two distinct layers of waste in the tank: a fluid upper layer and a thick slurry lower layer. Mixing of these waste layers is performed to gradually release radiochemically produced hydrogen and prevent the tank's periodic "burps". A modified version of the Hydrogen Mitigation Test Pump (Mixer Pump) can also be used in the retrieval mode where it will be used to remove fluid waste from the tank.

The Mixer Pump service environment in the waste tanks presents severe radiation, chemical and thermal conditions.

A severe environment qualification of the hydrogen mitigation test pump (Hydrogen Mitigation Test Pump \#1) was performed and reported in Reference 1. Hydrogen Mitigation Test Pump \#1 is presently installed in Waste Tank 241-SY-101. Hydrogen Mitigation Pump \#2, presently in storage, is a backup to Hydrogen Mitigation Pump \#1.

Hydrogen Mitigation Pump \#3 is presently undergoing engineering design and fabrication. Hydrogen Mitigation Pump \#3 is identical in design and fabrication to Hydrogen Mitigation Pump \#1, except for the capability to change the motor oil in Hydrogen Mitigation Pump \#3. Hydrogen Mitigation Pump \#3 has the same mitigation capability of the Hydrogen Mitigation Pump \#1 and can also perform in a retrieval mode. For this reason the motor/pump of Hydrogen Mitigation Pump \#3 is mounted lower in a tank necessitating a longer support column, and power and instrument cables. Hydrogen Mitigation Pump \#3 also uses a different power cable for the motor. This new cable must be qualified to operate in the severe thermal and radiation environment.

As with the Hydrogen Mitigation Test Pump \#1 severe environment qualification program, the qualification of the power cable for Hydrogen Mitigation Pump \#3 has been performed using Nuclear Regulatory Commission (NRC) and Institute of Electronic and Electrical Engineers (IEEE) guidance developed for qualifying equipment for nuclear power plants. The basis for this guidance consists of four documents: 
WHC-SD-WM-TI-758, Rev. 0

NRC 10CFR 50.49

Environmental Qualification of Electric Equipment Important to Safety for Nuclear Power Plants

NRC Regulatory Guide 1.89 (Revision 1) June 1984

Environmental Qualification of Certain Electric Equipment Important to Safety for Nuclear Power Plants

IEEE Standard $323-1974$ and 1983

Qualifying Class IE Equipment for Nuclear Power Generating Stations

IEEE Standard $383-1974$

Type Test of Class 1 E Electric Cables; Field Splicers and Connections for Nuclear Power Generating Stations.

The qualification program uses an "analysis methodology which is defined in IEEE Std 323 as:

"Logical assessment or valid mathematical model of equipment to be qualified. Qualification consists of quantitative analysis supported by test data, operating experience or physical laws of nature to demonstrate that equipment can perform under severe conditions."

This report presents the severe environment qualification of the power cable in severe radiation and thermal conditions. This qualification program provides Westinghouse Hanford Company information for the use of the new cable in the mixer pump for hydrogen mitigation and retrieval purposes. 
WHC-SD-WM-TI-758, Rev. 0

\subsection{EQUIPMENT}

The Mixer Pumps consist of four equipment subsystems: the motor/pump, the mechanical structure, instrumentation packages, and the control system.

A review of the mixer pumps' equipment interaction with the severe radiation, thermal, and chemical environment yielded the following information:

\section{Motor/Pump}

In the motor/pump subsystem, the only components sensitive to the severe environment are the power cable, motor, oil and seals. The pump indexing equipment is located in the pump pit outside the severe environment.

\section{Mechanical Structure}

The mechanical structure is made of carbon and stainless steel. These materials are not affected by the radiation environment; however, they are susceptibility to chemical/thermal environments.

\section{Instrumentation Packages}

The operating instrumentation packages on the SY-101 Mixer Pump are temperature, pressure, moisture, vibration and strain sensors. Parameters monitored include discharge leg pressure, temperature, and flow; pump discharge plenum pressure; motor vibration, oil temperature, and moisture; mixer pump column bending. Some of these instruments are located in the severe environment and are susceptible to its effects; however, the failure of these components will not affect the pump's ability to operate satisfactorily.

\section{Control System}

The Control System is located outside the tank and is not affected by the severe environment. 
WHC-SD-WM-TI-758, Rev, 0

The power cable used in the Hydrogen Mitigation Pump \#3 was supplied by Radix Wire Company. The power cable specifications, requested by Westinghouse Hanford Company, were as follows:

Silicone rubber motor lead with K-fiber braid Type SRML-K, copper wire, Class $H$ stranding (350 kcmil-427 strands), $600 \mathrm{~V}, 125^{\circ} \mathrm{C}$ minimum, UL Style 3410 , Nuclear Radiation Resistance rated excellent, nominal O.D. 350 kcmil-1.06" maximum.

This cable is described by Radix Wire Company in Appendix A. Radix Wire Company Cable SRML-K is identical to SRK cable. The quality assurance element of this program established the equivalence for the two nomenclatures of the power cable. 


\subsection{SEVERE ENVIRONMENT CONDITIONS}

The power cable operates in thermal and radiation environments associated with the Hanford underground storage tanks as well as the stress associated with the pump's operation. In order to establish the service conditions for the power cable, the severe environments of Waste Tank 241-SY-101 (SY-101) were used as the baseline. The replacement pump will be installed in Tank SY-101 and will operated until removed or failure. The pump will be operated on a schedule consistent with tank safety considerations. The pump is assumed to operate in its "mixer mode" of three times per week, for 25 minutes each time. In addition, the pump will operate in a "retrieval mode" 24 hours per day for 4 weeks. Both the "mixer" and "retrieval" mode are included in this qualification testing. This operating scenario converts to a non-operating state of $97 \%$ and a mixer and retrieval operating state of $3 \%$. These percentages are of the time the pump is continuously in-place in the waste tank. This Hydrogen Mitigation Pump \#3 mixer pump is assumed to be installed on January 1, 1997.

\subsection{Thermal}

The SY-101 ambient waste temperature has been established at $118^{\circ} \mathrm{F}$ (SAIC 1995). This is the thermal environment of the pump under non-operating conditions. Engineering analysis on Hydrogen Mitigation Pump \#3, with the specified Radix cable, has established the cable temperature to be $257^{\circ} \mathrm{F}$ during pump operation (Merriman 1995).

\subsection{Radiation}

The radiation environment of the waste tank has been established using tank radiological sampling measurements. The details are presented by SAIC (1995). Allowances must be made for shielding of the cable by the exterior mechanical structure of the mixer pump. SAIC (1995) established a shielding factor of 2.9 between the dose rate and dose outside the pump and the exposure of the cable. In Table 1, the dose rate and integrated dose in the waste tank are estimated. This table also estimates the cable's integrated dose, including the shielding provided by the mixer pump's mechanical structure. 
WHC-SD-WM-TI-758, Rev. 0

Table 1. Dose and Dose Rate Baseline

\begin{tabular}{||r|r|r|c|c|}
\hline $\mathrm{CY}$ & Year & Dose Rate & Integrated Dose* & $\begin{array}{c}\text { Shielded } \\
\text { Cable }\end{array}$ \\
\hline 1997 & 0 & 758 & $0.0 \mathrm{E}+00$ & $0.0 \mathrm{E}+00$ \\
\hline 2002 & 5 & 676 & $3.1 \mathrm{E}+07$ & $1.1 \mathrm{E}+07$ \\
\hline 2007 & 10 & 602 & $5.9 \mathrm{E}+07$ & $2.0 \mathrm{E}+07$ \\
\hline 2012 & 15 & 537 & $8.4 \mathrm{E}+07$ & $2.9 \mathrm{E}+07$ \\
\hline 2017 & 20 & 479 & $1.1 \mathrm{E}+08$ & $3.7 \mathrm{E}+07$ \\
\hline 2022 & 25 & 427 & $1.3 \mathrm{E}+08$ & $4.4 \mathrm{E}+07$ \\
\hline 2027 & 30 & 380 & $1.4 \mathrm{E}+08$ & $5.0 \mathrm{E}+07$ \\
\hline 2032 & 35 & 339 & $1.6 \mathrm{E}+08$ & $5.5 \mathrm{E}+07$ \\
\hline 2037 & 40 & 302 & $1.7 \mathrm{E}+08$ & $6.0 \mathrm{E}+07$ \\
\hline 2042 & 45 & 269 & $1.9 \mathrm{E}+08$ & $6.4 \mathrm{E}+07$ \\
\hline 2047 & 50 & 240 & $2.0 \mathrm{E}+08$ & $6.8 \mathrm{E}+07$ \\
\hline \hline vear & vears & $\mathrm{rad} / \mathrm{hr}$ & $\mathrm{rad}$ & $\mathrm{rad}$ \\
\hline
\end{tabular}

* Dose rate and integrated dose are internal to waste tank, but external to pump.

For these estimates of radiation dose, the mixer pump is assumed to be installed in the waste tank on January 1, 1997. 
WHC-SD-WM-TI-758, Rev. 0

\subsection{QUALIFIED LIFE TESTING}

\subsection{Thermal and Radiation Testing}

National Technical Systems, Inc. (NTS), performed the thermal aging and radiation testing of the mixer pump cable. "Environmental Qualification Test Procedure for Cable Sample" (Appendix B) describes the test procedures and "National Technical Systems, Inc., Environmental Qualification Test Report for Cable Samples" (Appendix C) presents the results of this thermal aging and radiation testing.

Six 10 -foot sections of cable were provided to NTS for thermal and radiation testing. Five sections were used for testing and one was designated as spare.

For the thermal aging testing, the test procedure simulated non-operating thermal aging at $118^{\circ} \mathrm{F}$ for $97 \%$ of the time and mixer/retrieval operation at $257^{\circ} \mathrm{F}$ for $3 \%$ of the time. The cable sections were aged for equivalent service life of 20 years, 30 years, and 40 years. The thermal aging was followed by radiation exposure equivalent to 20 years, 30 years, and 40 years (i.e., $3.7 \times 10^{7}$ rads, $5.0 \times 10^{7}$ rads and $6.0 \times 10^{7}$ rads) service lives.

One section of cable was only thermally aged for 40 years, and another was only radiation tested for 40 years $\left(6.0 \times 10^{7}\right.$ rads $)$ service life.

\subsection{Thermal and Radiation Test Results}

The test results are presented in Appendix $C$. The cable successfully passed the thermal aging tests for the 20,30, and 40 years of service life. Upon radiation exposure for 20,30, and 40 years equivalents, the cable with 40 years thermal/radiation aging/exposure failed. The cables with 20 years thermal/radiation aging, and 30 years thermal/radiation aging passed the tests conducted to the guidelines of IEEE 323 and IEEE 383 for type tests of Class IE electric cables. 
WHC-SD-WM-TI-758, Rev. 0

\subsection{SUMMARY}

The power cable being used in Hydrogen Mitigation Pump \#3 has undergone thermal aging and radiation qualification testing. This cable manufactured by Radix Wire Company is a silicone rubber motor lead cable.

The baseline thermal and radiation environments used for the qualification testing are equivalent to the severe environments of waste Tank 241-SY-101 of the Hanford underground storage tanks. It is assumed the Hydrogen Mixer Pump \#3 is installed in the waste tank on January 1, 1997 and is non-operational $97 \%$ of the time and operational $3 \%$ of the time. The operation includes both mixing and retrieval.

The cable passed thermal aging qualification testing equivalent to 20,30 , and 40 year service life. Upon further exposure to 20,30 , and 40 year equivalent radiation environments, the cable exposed to the combined 20 and 30 year thermal/radiation environments passed the tests and are considered qualified to operate in these environments. The cable exposed to the combined 40 year thermal/radiation environments failed the tests and are not qualified to operate in this environment.

The cables exposed only to the 40 year thermal and 40 year radiation environments also passed the qualification tests. 
WHC-SD-WM-TI-758, Rev. 0

\subsection{REFERENCES}

1. Science Applications International Corporation, 1995, Severe Environments Qualification of SY-10I Hydrogen Mitigation Test Pump, WHC-SD-WM-IT-727.

2. R. E. Merriman, 1995, Design Analysis HMT \#3-1, WHC-Mitigation Equipment Engineering, September 21, 1995. 
WHC-SD-WM-TI-758, Rev. 0

APPENDIX A

Radix Wire Company

Power Cable Specifications

A-1 


\section{Radix}

FEATURES

- Superior abrosion ond cut:throught resistonce.

- High temperoture resisiont to $200^{\circ} \mathrm{C}$.

- Flexible.

- Moisure resistant.

- Fire resistont.

APPLICATIONS

- Above grode in roceway, conduit or internol witing of electicol equiprient.

- High temperouture locotions with some mechanicol obuse.

- Lead wire for hozardous locotion motors.

CONSTRUTION

- Anneoled timned copper; solid or stronded.

- Ozone resistont. silicone rubber insulation.

- KFiber outer broid, with a moisture, heot ond flome resistant finish.

- Outer Broid moy be color coded, black is stondord.

COMPLIANCE

- UL listed style 3410.

- Posses UL VW-1, IEEE-383 Verical Tray Flome Test.

- Silicona rubber insulotion meets requirem:ents of ICEA 5-19-81.

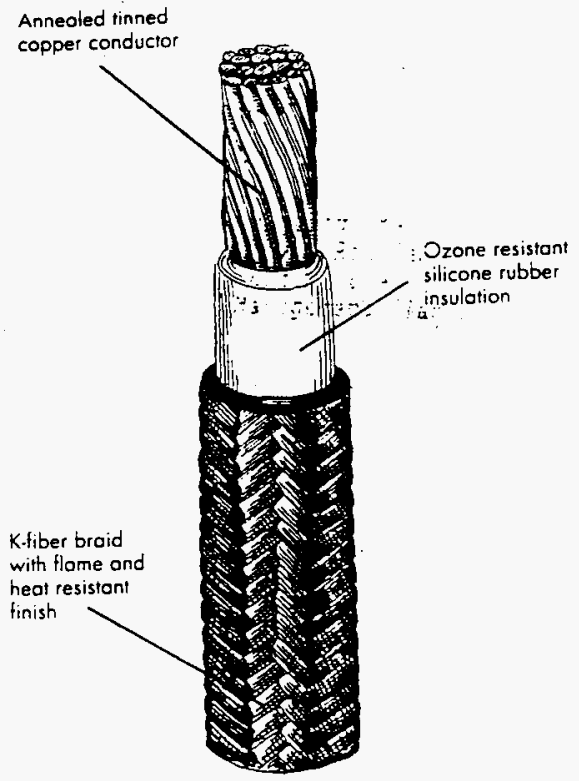

SRML-K is designed for use in high temperature opplications os o single conductor, flexible opporatus and lead wire where resistance to abrosion and mechonicol abuse is desired. This wire is widely used in steel and glass plants, as well as hazardous locotion motor leads. 


\begin{tabular}{|c|c|c|c|c|c|c|c|}
\hline $\begin{array}{c}\text { Part } \\
\text { Number }\end{array}$ & $\begin{array}{l}\text { Size } \\
\text { AWG/ } \\
M C M\end{array}$ & $\begin{array}{l}\text { Stronds/ } \\
\text { Strand } \\
\text { Diameter }\end{array}$ & $\begin{array}{l}\text { Conductor } \\
\text { Diomeler } \\
\text { (In] }\end{array}$ & $\begin{array}{l}\text { Insulation } \\
\text { Thickness } \\
\text { (in) }\end{array}$ & $\begin{array}{l}\text { Braid } \\
\text { Thickness } \\
\text { [n] }\end{array}$ & $\begin{array}{c}\text { Nominal } \\
\text { Diometer } \\
(\mid n)\end{array}$ & $\begin{array}{l}\text { Approximole } \\
\text { Weight } \\
\text { (bos/Mti) }\end{array}$ \\
\hline $\begin{array}{l}\text { KGG } 14 T 007 \\
\text { KGG12TO07 } \\
\text { KGGIOTO07 } \\
\text { KGG08TO54 } \\
\text { KGG06TO84 } \\
\text { KGGO4T133 } \\
\text { KGG02T259 } \\
\text { KGGO1T259 } \\
\text { KGGX1T259 } \\
\text { KGGX2T259 } \\
\text { KGGX3T259 } \\
\text { KGGX4T259 } \\
\text { KGG25T427 } \\
\text { KGG35T427 } \\
\text { KGG50T427 }\end{array}$ & $\begin{array}{r}14 \\
12 \\
10 \\
8 \\
6 \\
4 \\
2 \\
1 \\
1 / 0 \\
2 / 0 \\
3 / 0 \\
4 / 0 \\
250 \\
350 \\
500\end{array}$ & $\begin{array}{l}7 / 0242 \\
7 / 0305 \\
7 / 0385 \\
54 / 0177 \\
84 / 0177 \\
133 / 0177 \\
259 / 0160 \\
259 / 0180 \\
259 / 0202 \\
259 / 0227 \\
259 / 0255 \\
259 / 0286 \\
427 / 0242 \\
427 / 0286 \\
427 / 0342\end{array}$ & $\begin{array}{l}0.072 \\
0.088 \\
0.115 \\
0.142 \\
0.210 \\
0.262 \\
0.330 \\
0.365 \\
0.415 \\
0.465 \\
0.514 \\
0.590 \\
0.655 \\
0.775 \\
0.923\end{array}$ & $\begin{array}{l}0.045 \\
0.045 \\
0.045 \\
0.060 \\
0.060 \\
0.060 \\
0.060 \\
0.080 \\
0.080 \\
0.080 \\
0.080 \\
0.080 \\
0.095 \\
0.095 \\
0.095\end{array}$ & $\begin{array}{l}0.035 \\
0.035 \\
0.040 \\
0.040 \\
0.040 \\
0.040 \\
0.040 \\
0.040 \\
0.040 \\
0.040 \\
0.040 \\
0.040 \\
0.040 \\
0.040 \\
0.040\end{array}$ & $\begin{array}{l}0.236 \\
0.252 \\
0.289 \\
0.348 \\
0.420 \\
0.476 \\
0.544 \\
0.615 \\
0.665 \\
0.715 \\
0.764 \\
0.840 \\
0.939 \\
1.059 \\
1.213\end{array}$ & $\begin{array}{r}33.4 \\
43.9 \\
60.7 \\
94.2 \\
137.2 \\
193.2 \\
280.1 \\
359.9 \\
444.6 \\
534.4 \\
656.9 \\
811.4 \\
976.6 \\
1327.1 \\
1847.4\end{array}$ \\
\hline
\end{tabular}

Plecse Contect Our Fectery for Sizes or Iaformotion Hat listed.

All Dimonions ore Nemino:

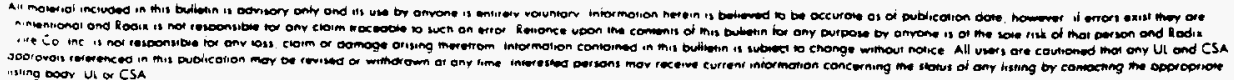
(4L) 
WHC-SD-WM-TI-758, Rev. 0

\section{APPENDIX B}

\section{Environmental Qualification Test Procedure for Cable Samples}




\section{Thबs \\ WHC-SD-WM-TI-758, Rev. 0}

Test Pracedure No. 60776-97N

Retision 0

ENVIRONMENTAL QUALIFICATION

TEST PROCEDURE FOR

CABIE SAMILES

FOR

SCIENCE APPLICATIONS INTERNATIONAL CORPORATION

3250 PORT OF BENTON BOULEYARD

RICENAND; WA 99352

Purctiese Order Number:

$13-270050-00$

Prepared by:

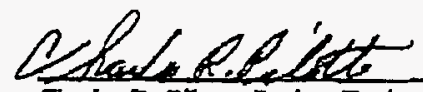

Charles R. Pilotte, Project Engineer, Nuclear Services

NTSANorthesst

Reviewed and Approted by:

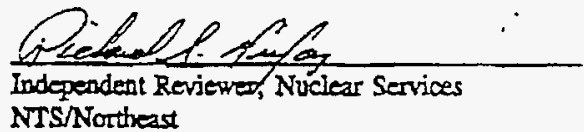

Date: 28 FE⿰氵

NTS/Notheast

Reriened and Approved by:

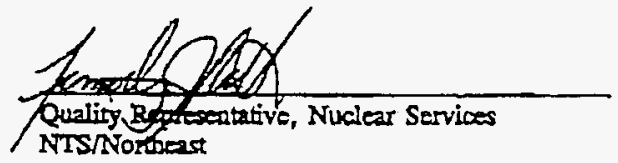

Date: 25 feb 96

Reriewed end Approved by:

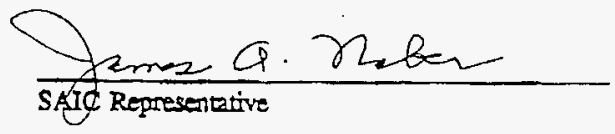

Date: 1 mane $9 L$

CRP/smV6077697.SAI

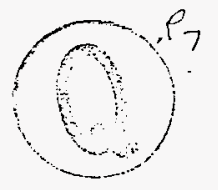

$$
B-2
$$




\section{ATES}

Test Procedure No. 60776-97N

Revision 0

9,

\section{ENVIRONMENTAL QUALIFICATION}

TEST PROCEDURE FOR

CABLE SAMPLES

FOR

\section{SCIENCE APPLICATIONS INTERNATIONAL CORPORATION}

3250 PORT OF BENTON BOULEVARD

RICHLAND, WA 99352

Purchase Order Number:

$13-970050-90$

Prepared by:

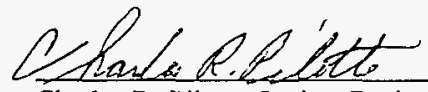

Charles R. Pilotte, Project Engineer, Nuclear Services

Date: 28 Fef 96 NTS/Northeast

Reviewed and Approved by:

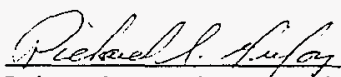

Date: $28 F F$ Independent Reviewer, Nuclear Services

NTS/Northeast

Reviewed and Approved by:

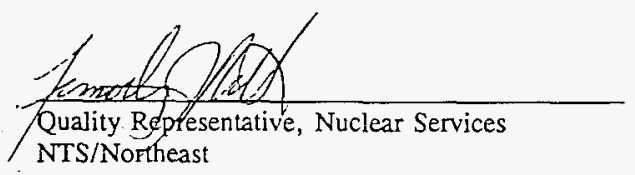

Date: $28 f e b \%$

Reviewed and Approved by:

Date: 


\section{atses}

\section{TABLE OF CONTENTS}

SECTION

PAGE NOS

1.0 SCOPE

$1-1$

2.0 APPLICABLE REFERENCE DOCUMENTS

$2-1$

3.0 COMPONENT DESCRIPTION

4.0 PROGRAM SEQUENCE

4-1

5.0 INCOMTNG INSPECTION/BASELINE FUNCTIONAL TESTING

$5-1$ to $5-2$

6.0 THERMAL AGING

$6-1$ to $6-4$

7.0 IRRADIATION

$7-1$ to $7-3$

8.0 TEST EQUIPMENT

8-1

9.0 FINAL DOCUMENTATION

$9-1$

APPENDIX A: SAMPLE TEST DATA SHEETS

A-1 to $A-4$ 


\section{MYSA}

\subsection{SCOPE}

The purpose of this qualification test procedure is to present the general requirements and methodology which shall be utilized to qualify the SAIC test items identified within Section 3.0 to the environmental conditions anticipated for its intended installation. The intent of the test program is to qualify the test items to encompass the aging requirements contained within SAIC Purchase order No. 13-970050-90. The test program is intended to meet the guidelines of IEEE 323-1983(R90) and IEEE 383-1974(R92) for type tests of Class 1E electric cables.

Specifically, this test procedure details the type testing techniques that will be utilized to provide SAIC with the environmental qualification data stipulated within SAIC Purchase Order 13-970050-90, dated 13 February 1996.

The qualification testing program outlined within this document shall be conducted in accordance with the NTS/Northeast Quality Manual, Revision 3, dated July 14, 1992. This insures that the applicable provisions of 10CFR, Part 21 and Part 50, Appendix B are fulfilled. 
arses

\subsection{APPLICABLE REFERENCE DOCUMENTS}

2.1 IEEE Std. 323-1983(R90), Qualifying Class 1E Equipment for Nuclear Power Generating Stations.

2.2 IEEE 383-1974(R92), Standard for Type Test of Class 1E Electric Cables, Field Splices, and Connections for Nuclear Power Generating Stations.

2.3 NTS/Northeast Quote Number 6-016-N5668.

2.4 Science Applications International Corporation, Purchase Order No. 13-970050-90, dated 13 February 1996.

2.5 NTS/Northeast Quality Manual, Revision 3, dated July 14, 1992.

2.6 Code of Federal Regulations, Title 10, Part 21, Reporting of Defects and Noncompliance

2.7 Code of Federal Regulations, Title 10, Part 50, Appendix B, Quality Assurance Criteria for Nuclear Power Plants and Fuel Reprocessing Plants

2.8 NTS/Northeast Audit Report No. NTS/A-93-030, dated May 12, 1993 of Isomedix, located in Whippany, NJ.

2.9 NTS/Northeast Report No. NTS/CGS-93-027 dated May 17, 1993 of Springborn Laboratories, located in Enfield, CT. 


\section{ahes}

\subsection{COMPONENT DESCRIPTION}

The following cable samples will be supplied by SAIC.

Qty 6 Sample Cables; Manufacturer: Radix Wire Co.; P/N SRML-K Radix; $1 / \mathrm{C}$ Silicone Rubber Insulation with K-Fiber jacket; $600 \mathrm{VAC}, 200^{\circ} \mathrm{C}$; UL Style 3410. Each sample 10 feet in length minimum.

Distributor: Anixter

Sample cables $1,2, \& 3$ shall undergo thermal/radiation aging.

Sample cable 4 shall undergo thermal aging only.

Sample cable 5 shall undergo radiation aging only.

Sample cable 6 is a spare cable and will have activation energy determination performed on insulation jacket. 
WHC-SD-WM-TI-758, Rev. 0

ahes

\subsection{PROGRAM SEQUENCE}

The environmental qualification shall be conducted in the following sequence:

1. Incoming Inspection

2. Baseline Functional Test

3. Thermal Aging

4. Post Thermal Aging Baseline Test

5. Irradiation

6. Post Irradiation Baseline Test

NOTE: The program sequence performed is per the request of SAIC.

Procedure No. 60776-97N 


\subsection{INCOMING INSPECTION/BASELINE FUNCTIONAL TESTING}

\subsection{Incoming Inspection}

Upon receipt of the test samples at NTS/Northeast, the test items described in Section 3.0 of this document shall be visually inspected to ensure there has been no damage due to shipping and handling and to confurm that the test item model numbers coincide with those listed in the packing list. Any anomalies shall be recorded and brought to the attention of SAIC. If there is no evidence of damage the items shall be logged in, tagged and proceed to testing.

\subsection{Baseline Functional Testing}

The cable sample numbers 1 through 5 with identification tags attached for traceability shall be coiled around mandrels of approximately 20 times the cable diameter. Each cable sample shall be coiled around the mandrel so that the affected section of each cable under test will be approximately 10 feet. Each cable sample shall then be subjected to the following tests.

A. Continuity Test - Measure and record the continuity of each cable sample.

B. Insulation Resistance - Submerge the test samples in tap water at room temperature. After a one (1) hour soak, measure and record the insulation resistance between the conductor and ground. A test voltage of 500 VDC will be applied for one (1) minute prior to the insulation resistance measurement.

\section{Acceptance Criteria}

Insulation resistance values should be $\geq 1.0$ megohms for each sample.

Procedure No. $\underline{60776-97 N}$ 


\section{arses}

WHC-SD-WM-TI-758, Rev. 0

\subsection{INCOMING INSPECTION/BASELINE FUNCTIONAL TESTING (continued)}

\subsection{Baseline Functional Testing (continued)}

C. Dielectric Withstanding Voltage - While still immersed, a test of $2 \mathrm{X}$ rated voltage plus $1000(2 \times 600+1000=2200 \mathrm{VAC})$ will be applied for five (5) minutes.

\section{Acceptance Criteria}

No leakage in excess of $5 \mathrm{~mA}$ shall occur. 


\section{MhAs}

\subsection{THERMAL AGING}

The following data shall be used to determine the accelerated aging times to provide a 20 year qualified service life for sample 1, 30 year qualified life for sample 2 and a 40 year qualified life for samples 3 and 4.

\subsection{Activation Energy (ev)}

The weak-link age sensitive material of the subject cables is the silicone-rubber insulation.

The activation energy value for this material has not been provided by SAIC or the manufacturer of the material. NTS/Northeast shall utilize sample cable 6 for determination of activation energy. Insulation samples shall be sent to Springborn Laboratories located in Enfield, CT for Thermo Gravimetric Analysis. (TGA).

Springborn Laboratories is an approved commercial grade vendor of NTS/Northeast. NTS/Northeast shall maintain under their QA program all records pertaining to Springborn Laboratories to assure compliance with 10CFR, Part 21 and Part 50, Appendix B.

Historical data shows that for cured silicone rubber typical activation energy values fall within the range of 1.5 to $2.5 \mathrm{ev}$. NTS/Northeast shall conservatively choose a value of $1.0 \mathrm{ev}$ for this program. Actual values determined by Springborn Laboratories will be included within the final test report.

Aging times based on activation energy value of $1.0 \mathrm{ev}$ will be utilized unless actual results from TGA analysis are lower, in which case, calculations will be adjusted. Actual anticipated values from analysis at this time are expected to exceed $1.5 \mathrm{ev}$.

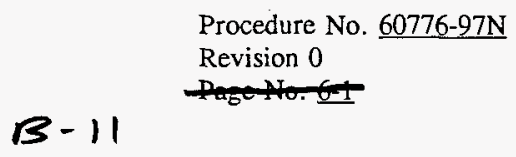

Procedure No. $\underline{60776-97 \mathrm{~N}}$

Revision 0 
MhAs

6.0 THERMAL AGING (continued)

\subsection{Service Conditions}

The following service temperature profile for the subject cables shall apply for each of the intended qualified service life periods $(20,30$ and 40 years).

\begin{tabular}{|c|c|c|}
\hline Non-operating & $118^{\circ} \mathrm{F}$ & $97 \%$ of time \\
\hline Mixer/Retrieval Operation & $257^{\circ} \mathrm{F}$ & $3 \%$ of time \\
\hline
\end{tabular}

Adding 10\% margin and converting to hours, the calculated service life becomes:

\section{A) $\underline{118^{\circ} \mathrm{F}\left(48^{\circ} \mathrm{C}\right)}$}

[20 years $(365$ days $/ y r)+5$ leap year days] $[24$ hrs/day $(1.1)(.97)]=187,066$ hours

[30 years $(365$ days $/ \mathrm{yr})+7$ leap year days] [24 hrs/day $(1.1)(.97)]=280,587$ hours

[40 years $(365$ days/yr) +10 leap year days] $[24$ hrs/day $(1.1)(.97)]=374,133$ hours

\section{B) $257^{\circ} \mathrm{F}\left(125^{\circ} \mathrm{C}\right)$}

[20 years $(365$ days $/$ yr $)+5$ leap year days $][24$ hrs/day $(1.1)(.03)]=5,786$ hours

[30 years $(365$ days $/$ yr $)+7$ leap year days] $[24$ hrs/day $(1.1)(.03)]=8,678$ hours

[40 years $(365$ days $/ \mathrm{yr})+10$ leap year days] $[24 \mathrm{hrs} /$ day $(1.1)(.03)]=11,571$ hours

\subsection{Aging Duration}

Using the Arrhenius Equation, the thermal aging time required to produce the applicable qualified service life for the subject cables plus $10 \%$ margin at the service temperature conditions given, can be calculated as follows:

$$
t_{2}=t_{1} \exp \left[\frac{\phi}{K}\left(\frac{1}{T_{2}}-\frac{1}{T_{1}}\right)\right]
$$


ALA

\subsection{THERMAL AGING (continued)}

\subsection{Aging Duration (continued)}

where:

$$
\begin{aligned}
& t_{2}=\text { Thermal Aging Time } \\
& t_{1}=\text { Service Life }
\end{aligned}
$$

$\begin{array}{llc} & \frac{118^{\circ} \mathrm{F}\left(48^{\circ} \mathrm{C}\right)}{187,066} \text { hours } & \frac{257^{\circ} \mathrm{F}\left(125^{\circ} \mathrm{C}\right)}{5,786 \text { hours }} \\ 30 \text { years } & 280,587 \text { hours } & 8,678 \text { hours } \\ 40 \text { years } & 374,133 \text { hours } & 11,571 \text { hours }\end{array}$

$$
\begin{aligned}
& \mathrm{T}_{1}=\text { Service Temperature }\left({ }^{\circ} \mathrm{K}\right)\left(118^{\circ} \mathrm{F}=321^{\circ} \mathrm{K} \text { and } 257^{\circ} \mathrm{F}=398^{\circ} \mathrm{K}\right) \\
& \mathrm{T}_{2}=\text { Thermal Aging Temperature }\left({ }^{\circ} \mathrm{K}\right) 448^{\circ} \mathrm{K} \\
& \phi=\text { Activation Energy }(1.0 \mathrm{eV}) \\
& \mathrm{K}=\text { Boltzmann's Constant }=.8617 \times 10^{-4} \mathrm{eV} /{ }^{\circ} \mathrm{K}
\end{aligned}
$$

The following table results in the calculated values for a 20,30 and 40 year qualified service life using an aging temperature of $175^{\circ} \mathrm{C}\left(448^{\circ} \mathrm{K}\right)$ for $\mathrm{T}_{2}$.

\begin{tabular}{|c|c|c|c|}
\hline Service Life & $118^{\circ} \mathrm{F}$ & $257^{\circ} \mathrm{F}$ & Total Hours \\
\hline \hline 20 years & 6.62 hours & 223.40 hours & 230 hours \\
\hline 30 years & 9.93 hours & 335.05 hours & 345 hours \\
\hline 40 years & 13.25 hours & 446.70 hours & 460 hours \\
\hline
\end{tabular}

Total hours tabulated have been rounded-off to nearest hours. The four (4) cables therefore shall be aged at $175^{\circ} \mathrm{C}$ as follows:

$$
\begin{array}{ll}
\text { Sample 1 } & 230 \mathrm{Hrs}=20 \text { Yrs }+10 \% \text { Margin } \\
\text { Sample 2 } & 345 \mathrm{Hrs}=30 \text { Yrs }+10 \% \text { Margin } \\
\text { Samples } 3 \& 4 & 460 \mathrm{Hrs}=40 \text { Yrs }+10 \% \text { Margin }
\end{array}
$$

During thermal aging the four (4) cables shall be mounted on mandrels. Thermal aging will be conducted within a forced hot-air temperature chamber. The aging oven temperature conditions will be continuously monitored and recorded. The test items will remain de-energized during aging. 
WHC-SD-WM-TI-758, Rev. 0

ares

6.0 THERMAL AGING (continued)

6.4 Post-Thermal Aging Baseline Test

Baseline functional testing as described in Section 5.2 shall be performed on all test items and results recorded on NTS/Northeast data sheets.

Following completion of post thermal testing the items shall be sent to Isomedix for Irradiation testing. 


\section{ahes}

\subsection{IRRADIATION}

The samples listed below mounted on mandrels of approximately 20 times the O.D. of the cable shall be carefully packaged and sent to Isomedix Inc., located in Whippany, NJ for irradiation exposure.

Isomedix is an approved vendor of NTS/Northeast and complies to the applicable requirements of $10 \mathrm{CFR}$, Part 21 and Part 50, Appendix B. An audit was performed on Isomedix which resulted with Isomedix being added to NTS/Northeast Approved Vendor listing under NTS/Northeast Audit Report No. NTS/A-93-030.

Four samples as identified shall undergo irradiation testing. The Total Integrated Dose shall be as follows for each sample.

$\begin{array}{lll}\text { Sample 1 } & 20 \text { Yrs } & 3.7 \times 10^{7} \text { Rads } \\ \text { Sample 2 } & 30 \text { Yrs } & 5 \times 10^{7} \text { Rads } \\ \text { Sample 3 } & 40 \text { Yrs } & 6 \times 10^{7} \text { Rads } \\ \text { Sample 5 } & & 6 \times 10^{7} \text { Rads }\end{array}$

The samples shall be oriented such that the irradiation source is uniformly dispersed. The samples shall be exposed to a Cobalt -60 gamma field, at a dose rate of between $5 \times 10^{5} \mathrm{rads}$ per hour and $1 \times 10^{6}$ rads per hour.

Halfway through the irradiation exposure the test samples shall be rotated $180^{\circ}$ (if required) to provide even distribution of gamma doses throughout the test samples.

Dosimetry will be performed using Harwell 4034 Red Perspex dosimeters, utilizing a Bausch and Lomb Model 1001 spectrophotometer as the readout instrument,or equivalent. This system is traceable to the National Institute of Standards and Technology (NIST). This system has a total uncertainty of $\pm 8 \%$ error. 
WHC-SD-WM-TI-758, Rev. 0

Alses

\subsection{IRRADIATION (continued)}

Upon completion of testing, Isomedix shall carefully package the test samples and return them to NTS/Northeast. The cables shall remain mounted on the mandrels to minimize any damaging of the cables from handling.

Isomedix shall issue documentation identifying the samples tested, Total Integrated Dose received and equipment utilized with certification to NIST. All documentation shall be certified by an authorized Quality Assurance representative of Isomedix. The documentation issued shall be made an attachment to the final report issued by NTS/Northeast to SAIC.

\subsection{Post Irradiation Baseline Test}

Following the Irradiation exposure and return to NTS/Northeast the samples shall be visually inspected for any signs of damage or deterioration. The results observed shall be documented on a NTS/Northeast test data sheet.

Following this the baseline functional testing described in Section 5.2 of this procedure shall be repeated, having the same acceptance criteria.

\subsection{1}

After completion of the baseline testing per Section 5.2, the following additional testing shall be performed.

A) While still immersed a Dielectric Voltage test shall be performed with a test potential of $80 \mathrm{VAC} / \mathrm{mil}$ thickness of insulation. The test potential of shall be applied for a duration of five (5) minutes. Actual mil thickness of the insulation jacket shall be measured and recorded by NTS/Northeast.

B) Upon completion of step A, the cables shall be removed from the bath and allowed to dry for 24 hours. Next, the cables shall be removed from the mandrels and straightened. Following this, the cable shall be reversed wraped around the mandrels.

Procedure No. $60776-97 \mathrm{~N}$

Revision 0 


\section{ates}

7.0 IRRADIATION (continued)

7.1 Post Irradiation Baseline Test (continued)

7.1 .1 (continued)

C) The cables shall be submerged in the water bath and allowed to soak for a period of 1 hour.

D) A test potential of $80 \mathrm{VAC} / \mathrm{mil}$ thickness of insulation shall be applied again for a period of five (5) minutes.

\section{Acceptance Criteria}

Leakage current shall not exceed 5 maAc.

Note: The acceptance value of 5 maAc is the limits of NTS/Northeast test equipment. If leakage values of 5 maAc are achieved, NTS/Northeast will document the maximum voltage achieved. Results of steps A through D are for informational purposes only. 


\section{ATAS}

\subsection{TEST EQUIPMENT REQUIREMENTS}

All test equipment used for this program shall be checked prior to testing to assure that it is in calibration and that the parameters being measured are appropriate for the range on the measuring instrument.

Calibration is performed and checked on a routine basis using standards traceable to the National Institute of Standards and Technology (NIST). Calibration of equipment is performed in accordance with the NTS quality program.

A list of test equipment used and verification of the suitability of the measuring instrument shall be included in the final report and will document the type of equipment, accuracies, and calibration due date as a minimum. 
WHC-SD-WM-TI-758, Rev. 0

设原

9.0 FINAL DOCUMENTATION

Upon completion of the environmental qualification testing, NTS/Northeast will submit a single test report to SAIC. This report will include, but not be limited to, the following:

1. A detailed description of the test items with photographs for identification.

2. Results of all functional tests, including methods and equipment used.

3. A detailed description of the test setups used including photographs.

4. Thermal aging temperature recording.

5. A list of all test equipment used, the last date of calibration and frequency of calibration. (Note: All equipment is calibrated with traceability to the National Institute of Standards and Technology (NIST). The detailed records are available for review and audit at NTS/Northeast).

If applicable, anomalous results and failure to meet acceptance criteria will be noted in the test report.

Procedure No. 60776-97N

Revision 0 
WHC-SD-WM-TI-758, Rev. 0

Ahas

\section{APPENDIX A: TEST DATA SHEETS}

Procedure No. 60776-97N

Revision 0

Page No 1 -1

B. 20 
DATA SHEET

\begin{tabular}{|c|c|c|c|c|}
\hline Job Number & $60776-97 \mathrm{~N}$ & Date & Page & of \\
\hline Customer & SAIC & \multicolumn{2}{|c|}{ Specification } & T.P. $60776-97 \mathrm{~N}$ \\
\hline Test Sample & Cable & \multicolumn{2}{|c|}{ Model/Serial No. } & SRML-K \\
\hline Test & Baseline & \multicolumn{2}{|c|}{ Mode of Operation } & Insulation Resistance \\
\hline Purchase Order No. & $13-970050-90$ & & & \\
\hline
\end{tabular}

Remarks Cables submerged in water bath.

Apply 500 VDC for a period of one (1) minute.

Value of IR measured to be $\geq 1 \times 10^{6}$ ohms.

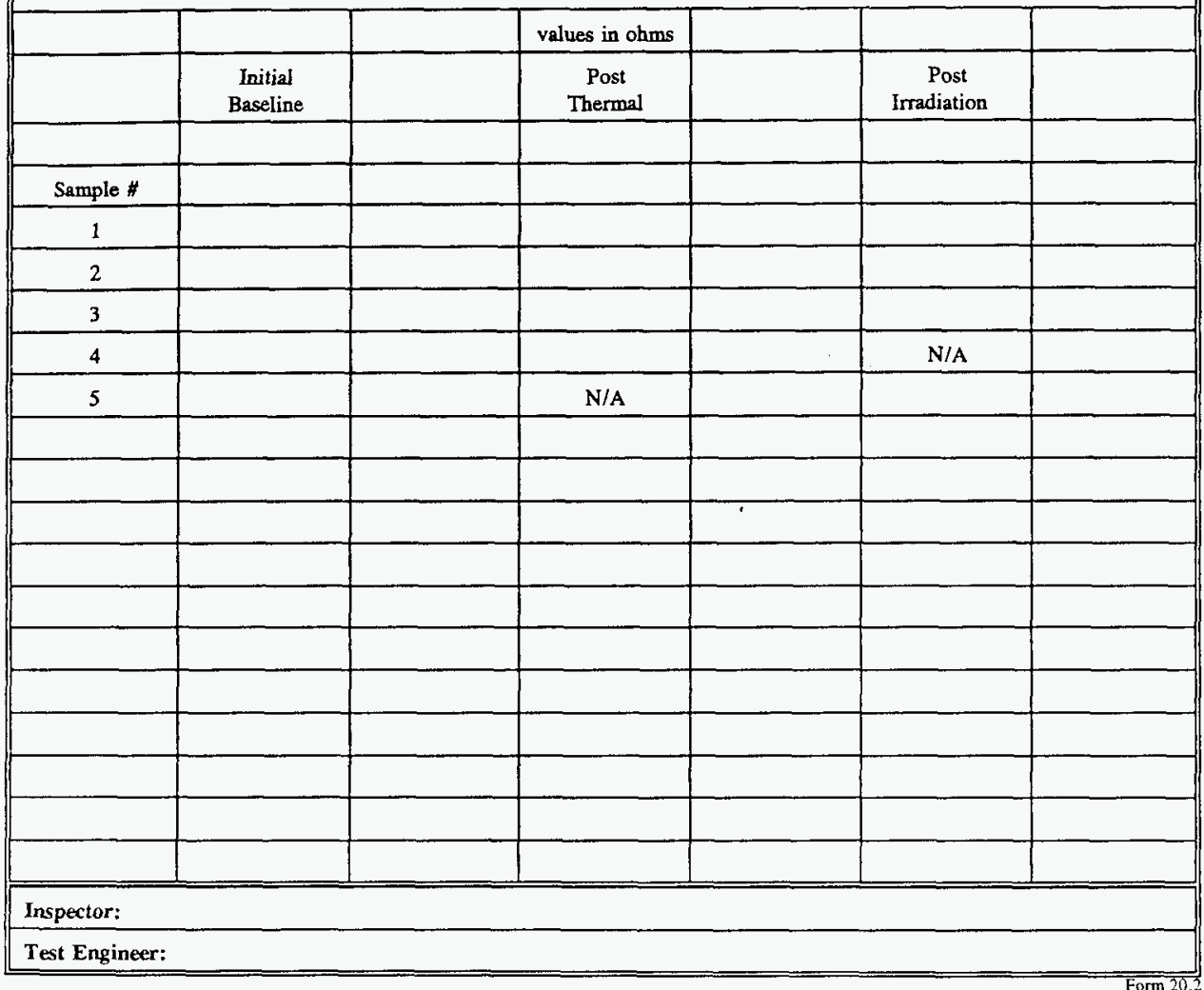

Procedure No. 60776-97N

Revision 0

Dage $\mathrm{N}_{0.12}$ 


\section{ases}

DATA SHEET

\begin{tabular}{|c|c|c|c|c|}
\hline Job Number & $60776-97 \mathrm{~N}$ & Date & Page & of \\
\hline Customer & SAIC & \multicolumn{2}{|c|}{ Specification } & T.P. $60776-97 \mathrm{~N}$ \\
\hline Test Sample & Cable & \multicolumn{2}{|c|}{ Model/Serial No. } & SRML-K \\
\hline Test & Baseline & \multicolumn{2}{|c|}{ Mode of Operation } & Dielectric Voltage \\
\hline Purchase Order No. & $13-970050-90$ & & & @2200 VAC \\
\hline
\end{tabular}

Remarks

Cables submerged in water bath.

Apply $2200 \mathrm{VAC}$ for a duration of 5.0 minutes

Leakage current to be $5 \mathrm{MaAc}$ or less.

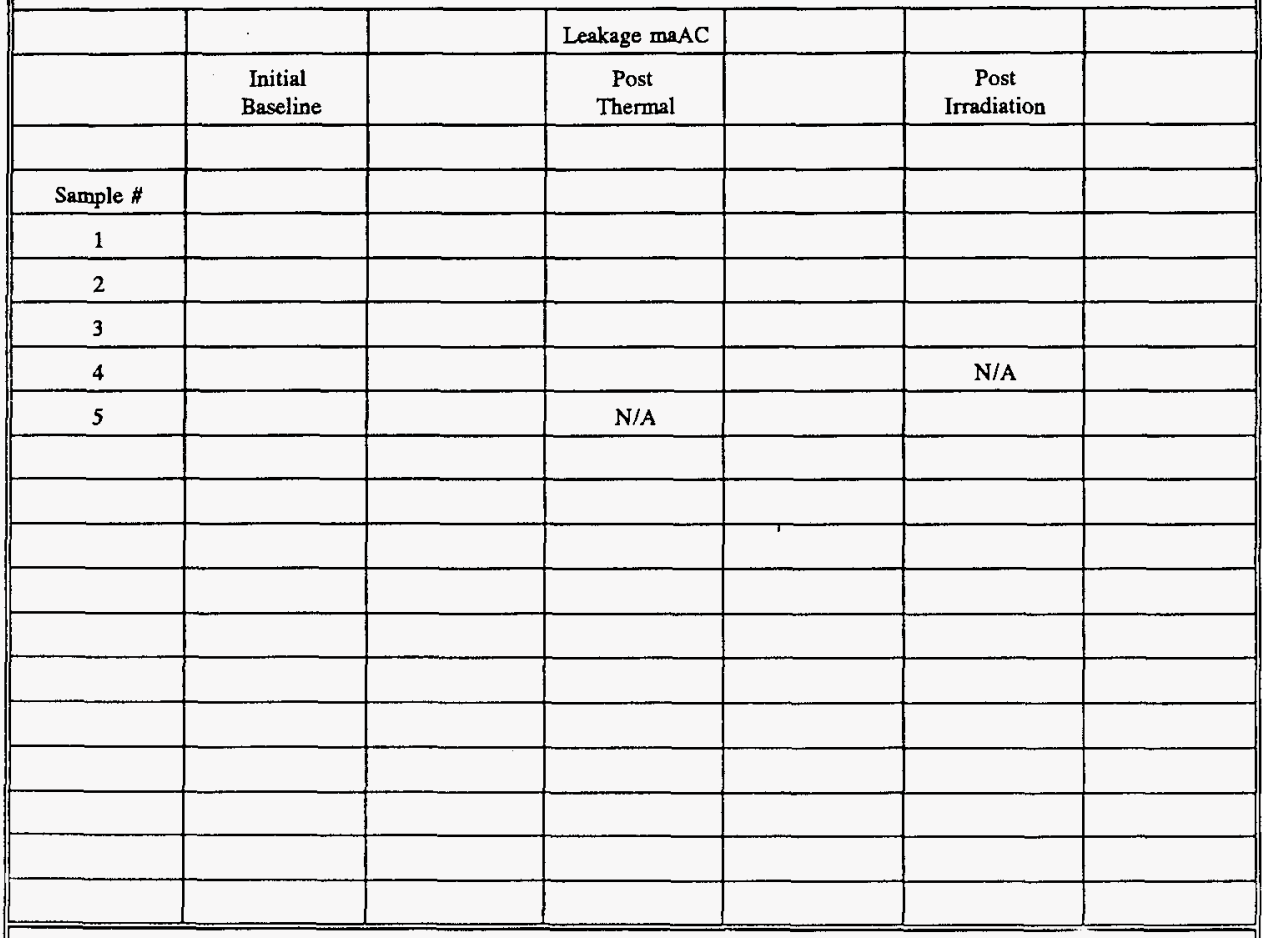

Inspector:

Test Engineer: 


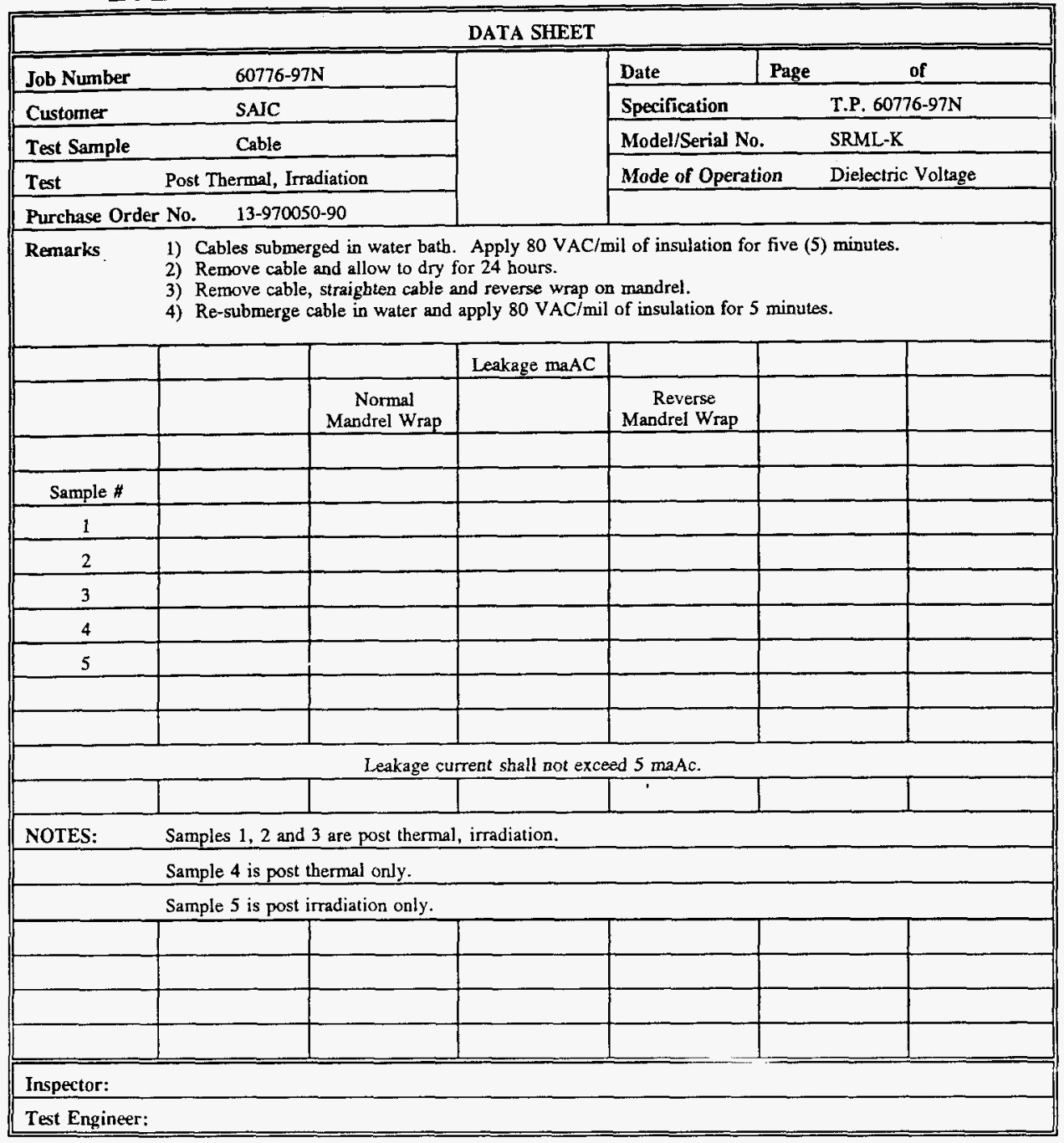


WHC-SD-WM-TI-758, Rev. 0

\section{APPENDIX C}

National Testing Systems, Inc.

Environmental Qualification Test

Report for Cable Samples

$B-24$ 


\section{ates}

Test Report No. 60776-97N

Revision 0

\section{ENVIRONMENTAL QUALIFICATION \\ TEST REPORT FOR \\ CABLE SAMPLES}

FOR

SCIENCE APPLICATIONS INTERNATIONAL CORPORATION

3250 PORT OF BENTON BOULEVARD

RICHLAND, WA 99352

Purchase Order Number:

$13-970050-90$

Prepared by:

Reviewed and Approved by:

Reviewed and Approved by:

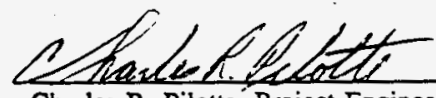

Charles R. Pilotte, Project Engineer, Nuclear Services NTS/Northeast

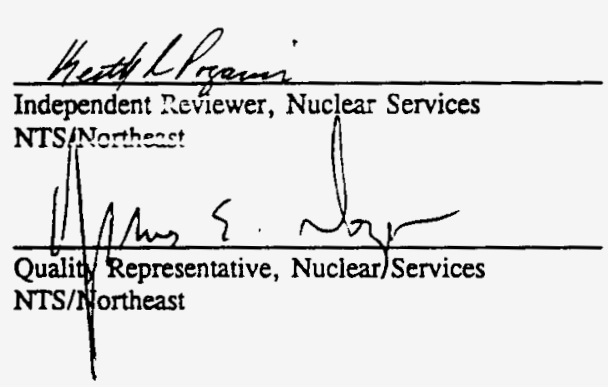

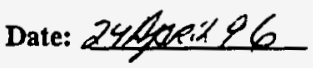

Date: 25 Afere 1946

Date: $4 / 25 / 96$ 


\section{AhAS}

\section{TABLE OF CONTENTS}

\section{SECTION}

PAGENOS

1.0 SCOPE

$1-1$

2.0 APPLICABLE REFERENCE DOCUMENTS

3.0 COMPONENT DESCRIPTION

4.0 PROGRAM SEQUENCE

5.0 INCOMING INSPECTION/BASELINE FUNCTIONAL TESTING

5-1 to 5-2

6.0 THERMAL AGING 6-1 to 6-4

7.0 IRRADIATION

7-1 to $7-3$

8.0 CONCLUSIONS AND OBSERVATIONS

8-1 to 8-2

9.0 TEST EQUIPMENT LIST

9-1 to $9-2$

APPENDIX A: $\quad$ NTS TEST DATA SHEETS

A-1 to $A-4$

APPENDIX B:

ANALYTICAL REPORT BY SPRINGBORN

B-1 to B-9 LABORATORIES

APPENDIX C: $\quad$ THERMAL AGING CHARTS

C-1 to C-23

APPENDIX D: ISOMEDIX REPORT

D-1 to D-5

APPENDIX E: PHOTOGRAPHS

E-1 to E-3 


\section{ares}

\subsection{SCOPE}

The purpose of this qualification test report is to present the general requirements and methodology which was utilized to qualify the SAIC test items identified within Section 3.0 to the environmental conditions anticipated for its intended installation. The intent of the test program was to qualify the test items to encompass the aging requirements contained within SAIC Purchase order No. 13-970050-90. The test program was conducted to the guidelines of IEEE 323-1983(R90) and IEEE 383-1974(R92) for type tests of Class IE electric cables.

Specifically, this test report details the type testing techniques that were utilized to provide SAIC with the environmental qualification data stipulated within SAIC Purchase Order 13-970050-90, dated 13 February 1996 and the results of the testing activities.

The qualification testing program outlined within this report was conducted in accordance with the NTS/Northeast Quality Manual, Revision 3, dated July 14, 1992. This insures that the applicable provisions of 10CFR, Part 21 and Part 50, Appendix B are fulfilled. 


\section{ALES}

\subsection{APPLICABLE REEERENCE DOCUNTSTS}

2.1 IEEE Std. 323-1983(R90), Qualifyine Class IE Equipment for Nuclear Power Generating Stations.

2.2 IEEE 383-1974(R92), Standard for Type Test of Class IE Electric Cables. Field Splices. and Connections for Nuclear Power Generating Stations.

2.3 NTS/Northeast Quote Number 6-016-N5668.

2.4 Science Applications Intemational Corporation, Purchase Order No. 13-970050-90, dated 13 Febriary 1996.

2.5 NTS/Northeast Quality Manual, Revision 3, dated July 14, 1992.

2.6 Code of Federal Regulations, Title 10, Part 21, Reportine of Defects and Noncompliance

2.7 Code of Federal Reguiations, Title 10, Part 50, Appendix B, Quality Assurance Criteria for Nuclear Power Plants and Euel Reprocessing Plants

2.8 NTS/Northeast Audit Report No. NTS/A-93-030, dated May 12, 1993 of Isomedix, located in Whippany, NJ.

2.9 NTS/Northeast Report No. NTS/CGS-93-027 dated May 17, 1993 of Springborn Laboratories, located in Enfield, CT.

2.10 NTS/Northeast Test Procedure No. 60776-97N, Rev. 0, dated 1 March 1996. 
atres

\subsection{COMPONENT DESCRIPTION}

The following cable samples were supplied by SAIC.

Oty 6 Sample Cables; Manufacturer: Radix Wire Co.; P/N SRML-K Radix; $1 / \mathrm{C}$ Silicone Rubber Insulation with K-Fiber jacket; $600 \mathrm{VAC}, 200^{\circ} \mathrm{C}$; UL Style 3410 . Each sample 10 feet in length minimum.

Distributor: Anixter

Sample cables 1, 2, \& 3 underwent thermal/radiation aging.

Sample cable 4 underwent thermal aging only.

Sample cable 5 underwent radiation aging only.

Sample cable 6 was a spare cable and had activation energy determination performed on the insulation jacket. 


\section{ares}

\subsection{PROGRAM SEOUENCE}

The environmental qualification was conducted in the following sequence:

1. Incoming Inspection

2. Baseline Functional Test

3. Thermal Aging

4. Post Thermal Aging Baseline Test

5. Irradiation

6. Post Irradiation Baseline Test

NOTE: The program sequence performed was per the request of SAIC. 


\section{AhAs}

\subsection{INCOMING NSPECTION/BASELINE FUNCTIONAL TESTING}

\subsection{Ineorming Inspection}

Upon receipt of the test samples at NTS/Northeast, the test items described in Section 3.0 of this document were visually inspected to ensure there has been no damage due to shipping and handling and to confirm that the test item model numbers coincide with those listed in the packing list. There was no evidence of damage and the items were logged in, tagged and proceeded to testing.

\subsection{Baseline Functional Testing}

The cable sample numbers 1 through 5 with identification tags attached for traceability were coiled around mandrels having a diameter of 18 inches. Each cable sample was coiled around the mandrel so that the affected section of each cable under test was approximately 10 feet. Each cable sample was then subjected to the following tests. Appendix A of this report contains actual data sheets and values recorded.

A. Continuity Test - Measure and record the continuity of each cable sample.

B. Insulation Resistance - Submerge the test samples in tap water at room temperature. After a one (1) hour soak, measure and record the insulation resistance between the conductor and ground. A test voltage of $500 \mathrm{VDC}$ will be applied for one (1) minute prior to the insulation resistance measurement.

\section{Results}

Insulation resistance values were $\geq 1.0$ megohms for each sample. 
5.0 INCOMING INSPECTION/BASELINE FUNCTIONAL TESTING (continued)

\subsection{Baseline Functional Testing (continued)}

C. Dielectric Withstanding Voltage - While still immersed, a test of $2 X$ rated voltage plus $1000(2 \times 600+1000=2200 \mathrm{VAC})$ was applied for five (5) minutes.

\section{Results}

No leakage in excess of $5 \mathrm{mAAC}$ occurred. Actual leakage average was $1.9 \mathrm{mAAC}$ for initial baseline, $2.03 \mathrm{mAAC}$ for post thermal and $2.05 \mathrm{mAAC}$ for post irradiation. For a test potential of $2200 \mathrm{VAC}, 60 \mathrm{~Hz}$, this results in an impedance of $1.16 \times 10^{6}$ ohms for initial baseline, $1.08 \times 10^{6}$ ohms for post thermal and $1.07 \times 10^{5}$ ohms for post irradiation. Actual values recorded for each cable are contained within Appendix A of this report. 


\section{ATES}

\subsection{THERMAL AGING}

The following data was used to determine the accelerated aging times to provide a 20 year qualified service life for sample 1, 30 year qualified life for sample 2 and a 40 year qualified life for samples 3 and 4.

\subsection{Activation Energy (ev)}

The weak-link age sensitive material of the subject cables is the silicone-rubber insulation.

The activation energy value for this material had not been provided by SAIC or the manufacturer of the material. NTS/Northeast utilized sample cable 6 for determination of activation energy. Insulation samples were sent to Springbom Laboratories located in Enfield, CT for Thermo Gravimetric Analysis. (TGA).

Springbom Laboratories is an approved commercial grade vendor of NTS/Northeast. NTS/Northeast maintains under their QA program all records pertaining to Springborn Laboratories to assure compliance with 10CFR, Part 21 and Part 50, Appendix B.

Historical data shows that for cured silicone rubber typical activation energy values fall within the range of 1.5 to $2.5 \mathrm{ev}$. NTS/Northeast conservatively used a value of $1.0 \mathrm{ev}$ for this program. Actual values determined by Springborn Laboratories were 1.43 to $1.61 \mathrm{eV}$ depending on weight loss. Appendix B of this report contains the analytical report provided by Springborn Laboratories.

Aging times based on activation energy value of $1.0 \mathrm{ev}$ were utilized which provided an adequate margin of conservatism. 
ahes

\subsection{THERMAL AGING (continued)}

\subsection{Service Conditions}

The following service temperature profile for the subject cables applies for each of the intended qualified service life periods $(20,30$ and 40 years).

\begin{tabular}{|c|c|c|}
\hline Non-operating & $118^{\circ} \mathrm{F}$ & $97 \%$ of time \\
\hline Mixer/Retrieval Operation & $257^{\circ} \mathrm{F}$ & $3 \%$ of time \\
\hline
\end{tabular}

Adding $10 \%$ margin and converting to hours, the calculated service life becomes:

\section{A) $118^{\circ} \mathrm{F}\left(48^{\circ} \mathrm{C}\right)$}

[20 years (365 days/yr) +5 leap year days] [24 hrs/day $(1.1)(.97)]=187,066$ hours

[30 years $(365$ days $/ \mathrm{yr})+7$ leap year days] [24 hrs/day $(1.1)(.97)]=280,587$ hours [ 40 years $(365$ days $/ \mathrm{yr})+10$ leap year days] $[24 \mathrm{hrs} /$ day $(1.1)(.97)]=374,133$ hours

B) $257^{\circ} \mathrm{F}\left(125^{\circ} \mathrm{C}\right)$

[20 years $(365$ days $/ \mathrm{yr})+5$ leap year days] $[24 \mathrm{hrs} /$ day $(1.1)(.03)]=5,786$ hours [30 years $(365$ days $/ \mathrm{yr})+7$ leap year days] $[24 \mathrm{hrs} /$ day $(1.1)(.03)]=8,678$ hours [40 years $(365$ days $/ \mathrm{yr})+10$ leap year days] $[24 \mathrm{hrs} /$ day $(1.1)(.03)]=11,571$ hours

\subsection{Aging Duration}

Using the Arrhenius Equation, the thermal aging time required to produce the applicable qualified service life for the subject cables plus $10 \%$ margin at the service temperature conditions given, was calculated as follows:

$$
t_{2}=t_{1} \exp \left[\frac{\phi}{K}\left(\frac{1}{T_{2}}-\frac{1}{T_{1}}\right)\right]
$$




\subsection{THERMAL AGING (continued)}

\subsection{Aging Duration (continued)}

where:

$t_{2}=$ Thermal Ajing Time
$t_{1}=$ Service Life

20 years

30 years

40 years $118^{\circ} \mathrm{F}\left(48^{\circ} \mathrm{C}\right)$

187,066 hours 280,587 hours 374,133 hours $257^{\circ} \mathrm{F}\left(125^{\circ} \mathrm{C}\right)$

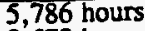

8,678 hours

11,571 hours

$\mathrm{T}_{1}=$ Service Temperature $\left({ }^{\circ} \mathrm{K}\right)\left(118^{\circ} \mathrm{F}=321^{\circ} \mathrm{K}\right.$ and $\left.257^{\circ} \mathrm{F}=398^{\circ} \mathrm{K}\right)$

$\mathrm{T}_{2}=$ Thermal Aging Temperature $\left({ }^{\circ} \mathrm{K}\right) 448^{\circ} \mathrm{K}$

$\phi=$ Activation Energy $(1.0 \mathrm{eV})$

$\mathrm{K}=$ Boltzmann's Constant $=.8617 \times 10^{-1} \mathrm{eV} /{ }^{\circ} \mathrm{K}$

The following table results in the calculated values for a 20,30 and 40 year qualified service life using an aging temperature of $175^{\circ} \mathrm{C}\left(448^{\circ} \mathrm{K}\right)$ for $T_{2}$.

\begin{tabular}{|c|c|c|c|}
\hline Service Life & $118^{\circ} \mathrm{F}$ & $257^{\circ} \mathrm{F}$ & Total Hours \\
\hline \hline 20 years & 6.62 hours & 223.40 hours & 230 hours \\
\hline 30 years & 9.93 hours & 335.05 hours & 345 hours \\
\hline 40 years & 13.25 hours & 446.70 hours & 460 hours \\
\hline
\end{tabular}

Total hours tabulated were rounded-off to nearest hours. The four (4) cables therefore were aged at $175^{\circ} \mathrm{C}$ as follows:

$\begin{array}{ll}\text { Sample 1 } & 230 \mathrm{Hrs}=20 \mathrm{Yrs}+10 \% \text { Margin } \\ \text { Sample 2 } & 345 \mathrm{Hrs}=30 \mathrm{Yrs}+10 \% \text { Margin } \\ \text { Samples 3 \& } 4 & 460 \mathrm{Hrs}=40 \mathrm{Yrs}+10 \% \text { Margin }\end{array}$

During thermal aging the four (4) cables were mounted on mandrels. Thermal aging was conducted within a forced hot-air temperature chamber. The aging oven temperature conditions were continuously monitored and recorded. The test items remained de-energized during aging. Each cable sample was removed from the chamber when the appropriate aging time had elapsed. Appendix C contains actual chart recordings and Appendix E contains photographs.

Report No. 60776-97N

Revision 0

Dago-Non 63 


\section{ares}

\subsection{THERMALAGING (continued)}

\subsection{Post-Thermal Aging Baseline Test}

Baseline functional testing as described in Section 5.2 was performed on all test items and results recorded on NTS/Northeast data sheets contained within Appendix A.

\section{Results}

Visual observation showed that all cables had some darkening of the silicone insulation and tarnishing of wire conductor strands.

All cable samples had insulation resistance and dielectric voltage results which met the original acceptance criteria. See data sheets contained in Appendix A.

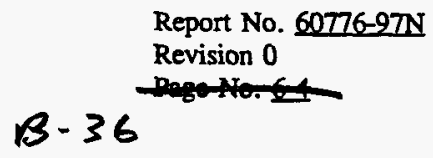




\section{ares}

\subsection{IRRADIATION}

The samples listed below mounted on mandrels of approximately 18 inch diameter were carefully packaged and sent to Isomedix Inc., located in Whippany, NJ for irradiation exposure.

Isomedix is an approved vendor of NTS/Northeast and complies to the applicable requirements of $10 \mathrm{CFR}$, Part 21 and Part 50, Appendix B. An audit was performed on Isomedix which resulted with Isomedix being added to NTS/Northeast Approved Vendor listing under NTS/Northeast Audit Report No. NTS/A-93-030.

Four samples as identified underwent irradiation testing. The Total Integrated Dose was as follows for each sample.

$\begin{array}{lll}\text { Sample 1 } & 20 \text { Yrs } & 3.7 \times 10^{7} \text { Rads } \\ \text { Sample 2 } & 30 \text { Yrs } & 5 \times 10^{7} \text { Rads } \\ \text { Sample 3 } & 40 \text { Yrs } & 6 \times 10^{7} \text { Rads } \\ \text { Sample 5 } & & 6 \times 10^{7} \text { Rads }\end{array}$

The samples were oriented such that the irradiation source was uniformly dispersed. The samples were exposed to a Cobalt -60 gamma field, at a dose rate of between $5 \times 10^{5}$ rads per hour and $1 \times 10^{6}$ rads per hour.

Per Isomedix the samples were rotated in $90^{\circ}$ turns during irradiation to insure even exposure. To prevent shielding effects from solid mandrels, NTS/Northeast transferred the cables to mandrels of the same diameter constructed of wire mesh to allow for full penetration. This was done without the coils being uncoiled, as they were slid from one mandrel to another and accomplished prior to sending the cables to Isomedix.

Dosimetry was performed using Harwell 4034 Red Perspex dosimeters, utilizing a Bausch and Lomb Model 1001 spectrophotometer as the readout instrument,or equivalent. This system is traceable to the National Institute of Standards and Technology (NIST). This system has a total uncertainty of $\pm 8 \%$ error.

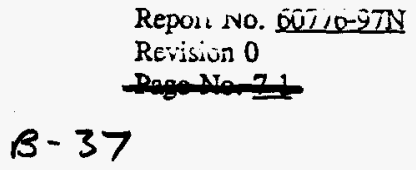




\subsection{IRRADIATION (continued)}

Upon completion of testing, Isomedix carefully packaged the test samples and retum them to NTS/Northeast. The cables remained mounted on the mandrels to minimize any damaging of the cables from handling and shipping. Upon retum of the cables to NTS/Northeast, the cables were inspected for visual signs of damage with none being noted.

Isomedix issued documentation identifying the samples tested, Total Integrated Dose received and equipment utilized with certification to NIST. All documentation was certified by an authorized Quality Assurance representative of Isomedix. The documentation issued is contained within Appendix D of this report.

\subsection{Post Irradiation Baseline Test}

The baseline function testing described in Section 5.2 of this report was repeated, having the same acceptance criteria.

\section{Results}

All cables met the acceptance criteria contained within Section 5.2.

\section{$7,1,1$}

After completion of the baseline testing per Section 5.2, the following additional testing was performed.

A) While still immersed, a Dielectric Voltage Test was performed with a test potential of $5400 \mathrm{VAC}$ to $5600 \mathrm{VAC}$, depending on the cable being tested. The potential was applied for a duration of five (5) minutes. The applied potential was limited to a measured leakage current of $5 \mathrm{mAAC}$, which is the limit of the NTS/Northeast tester.

B) Upon completion of step A, the cables were removed from the bath and allowed to dry for 24 hours. Next, the cables were removed from the mandrels and straightened. Following this, the cables were reversed wrapped around the mandrels.

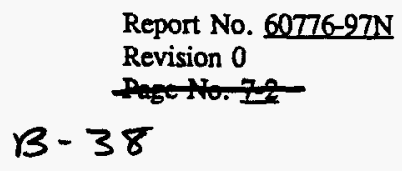




\subsection{IRRADIATION (continued)}

7.1 Post-Irradiation Baseline Test (continued)

7.1.1 (continued)

C) The cables were submerged in the water bath and allowed to soak for a period of 1 hour.

D) A test potential of $5400 \mathrm{VAC}$ to $5600 \mathrm{VAC}$ was applied again for a period of five (5) minutes.

\section{Results}

1. All cables met the acceptance criteria for insulation resistance and dielectric withstand voltage testing at $2200 \mathrm{VAC}$ and continuity testing.

2. Testing at elevated dielectric withstand voltages was limited to $5 \mathrm{mAAC}$, the maximum leakage current permissible by NTS/Northeast tester which resulted in test voltages of 5400 to $5600 \mathrm{VAC}$.

3. The resulting impedance at $5 \mathrm{mAAC}$ leakage current for potentials of 5400 to 5600 VAC results in values of $1.08 \times 10^{6}$ ohms to $1.12 \times 10^{6}$ ohms. This is consistent with those values determined at $2200 \mathrm{VAC}$, which yielded results of $1.07 \times 10^{6}$ ohms to $1.16 \times 10^{6}$ ohms. Therefore, the integrity of the cables insulation was upheld when tested at higher voltages, except for sample $\$ 3$ as detailed below.

4. On sample $\# 3$ the cable having been exposed to 40 year thermal/radiation failed to pass after having been reversed wrapped on the mandrel. A leakage of 5 mAAC was seen with only a potential of 5 VAC applied. Further discussion is provided in Section 8.0, Conclusions and Observations, of this report. 


\subsection{CONCLUSTONS AND OBSERVATIONS}

The cablesamples \#1 through 5 were aged as detailed in Sections 3.0,6.0 and 7.0 of this report. As a result of all testing, sample $\# 3$ failed to pass the reverse mandrel high voltage testing, which was the final phase of testing.

Suspect was that irradiation was a major contributor to cable embrittlement. To evaluate this at the completion of all testing sample $\# 3$ and sample $\# 4$ cables had a section of the K-fiber removed from the center length of each cabie. Sample $\# 4$ saw 40 years thermal aging, while sample \#3 saw 40 years thermal/radiation aging. On sample $\# 3$ a large crack around the circumference of the silicone rubber was found. No cracking of sample \#4 was noted. The cracks found on sample \#3 occurred during reverse mandrel wrapping of the cable because of embrittlement.

From each cable sample \#1 through 6 a piece of silicone rubber approximately $1^{1 / 2}$ inches in length was removed from the cable and examined for signs of embrittlement. Sample \#6 was a spare cable and was not aged. Silicone rubber from samples \#1 through 5 were compared against sample \#6. The following observations were noted.

On sample \#4 which was thermally aged only to 40 years, the silicone was found pliable, similar to sample \#6, the unaged cable. However, it was found that sample \#4 was less resistant to being tom indicating that some elasticity had been lost.

On samples $\# 1,2,3$ and 5 , all samples reveaied embrittlement. Sample $\# 5$ which received radiation only appeared equal to cracking and breaking of material when flexed when compared to sample $\# 3$.

Report No. 60776-97N Revision 0 
ares

\subsection{CONCLUSIONS AND OBSERVATIONS (continued)}

Samples \#1 and 2 had embrittlement but for each sample the silicone rubber could be flexed to a further degree before causing cracking.

Exposure to irradiation was the principle cause to embrittlement. All samples passed testing with the exception of sample \#3 undergoing the reverse mandrel wrap testing. Therefore, qualification to a 20 and 30 year life was achieved with the 40 year qualification attempt being unsuccessful.

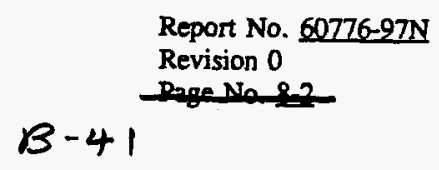




\section{ALES}

\subsection{TEST EOUIPMENT LIST}

All test equipment used for this program was checked prior to testing to assure that it was in calibration and that the parameters being measured were appropriate for the range on the measuring instrument.

Calibration is performed and checked on a routine basis using standards traceable to the National Institute of Standards and Technology (NIST). Calibration of equipment is performed in accordance with the NTS quality program.

A list of test equipment used and verification of the suitability of the measuring instrument is included on the following page. 
WHC-SD-WM-TI-758, Rev. 0

ATES

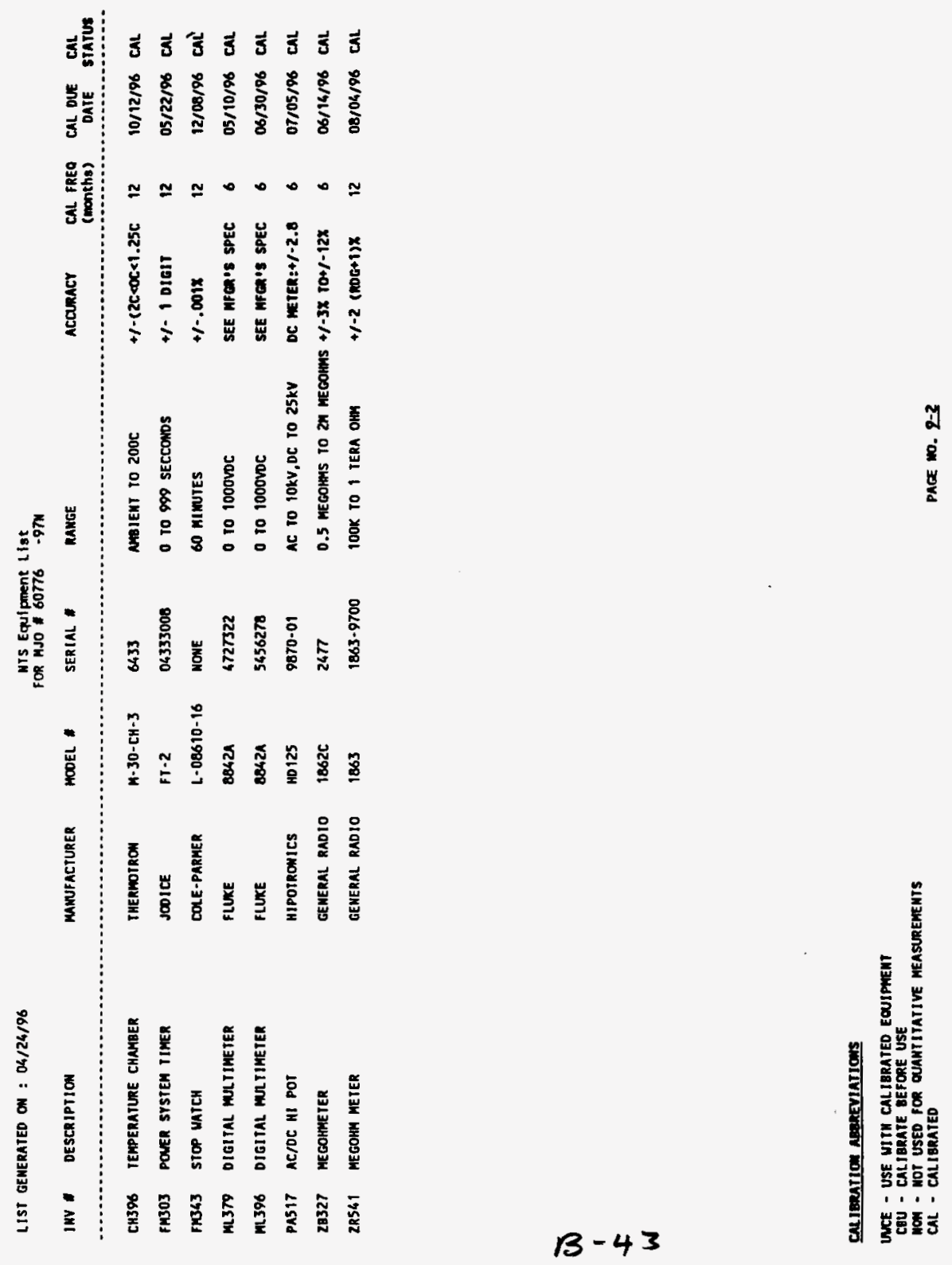


WHC-SD-WM-TI-758, Rev. 0

ahes

APPENDIX A

NTS TEST DATA SHEETS

Report No. 60776-97N

Revision 0

B-44 


\section{ates}

DATA SHEET

\begin{tabular}{|c|c|c|c|}
\hline Job Number & $60776-97 \mathrm{~N}$ & Date BCloar & Page $/$ \\
\hline Customer & SAIC & Specification & T.P. $60776-97 \mathrm{~N}$ \\
\hline Test Sample & Cable & Model/Serial No. & SRML-K \\
\hline Test & Baseline & Mode of Operatio & Insulation Resistance \\
\hline Purchase Order No. & $13-970050-90$ & & \\
\hline
\end{tabular}

Remariks Cables submerged in water bath.

Apply 500 VDC for a period of one (1) minute.

Value of IR measured to be $\geq 1 \times 10^{6}$ ohms.

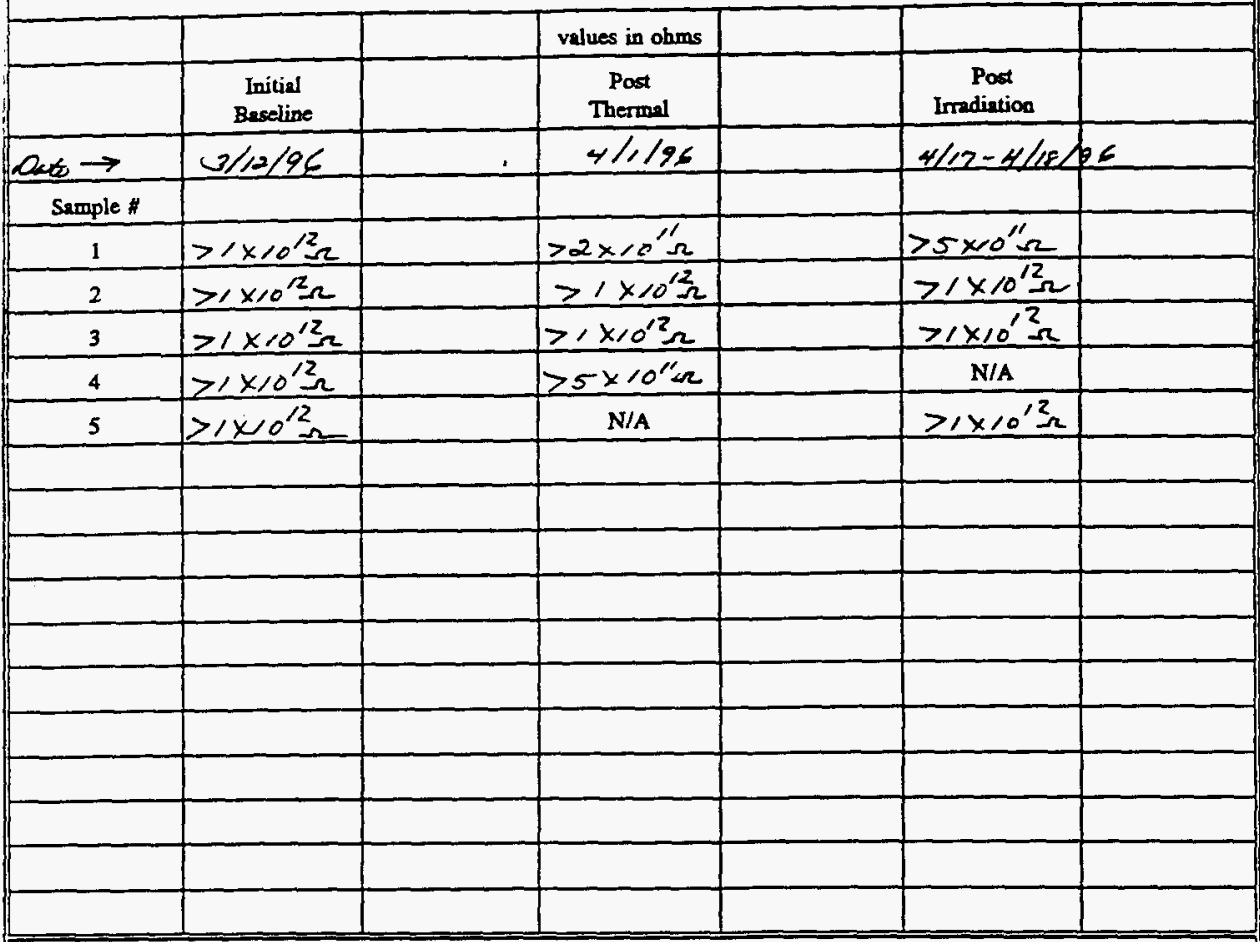

Inspector: 0 st 1 gu

Test Engineer:

Procedure No. 60776-97N

Revision 0 


\section{arses}

DATA SHEET

\begin{tabular}{|c|c|c|c|c|}
\hline Job Number & $60776-97 \mathrm{~N}$ & Date $\mathcal{B}_{\text {efow }}$ & Page & of \\
\hline Custamer & SAIC & Specification & \multicolumn{2}{|r|}{ T.P. 60776-97N } \\
\hline Test Sample & Cable & Model/Serial No. & \multicolumn{2}{|r|}{ SRML-K } \\
\hline Test & Baseline & Mode of Operatio & & Dielectric Voltnge \\
\hline Purchase Ord & $13-970050-90$ & \multicolumn{3}{|r|}{ (1) 2200 VAC } \\
\hline
\end{tabular}

Remarks Cables submerged in water bath.

Apply $2200 \mathrm{VAC}$ for a duration of 5.0 minutes

Leakage current to be $5 \mathrm{MaAc}$ or less.

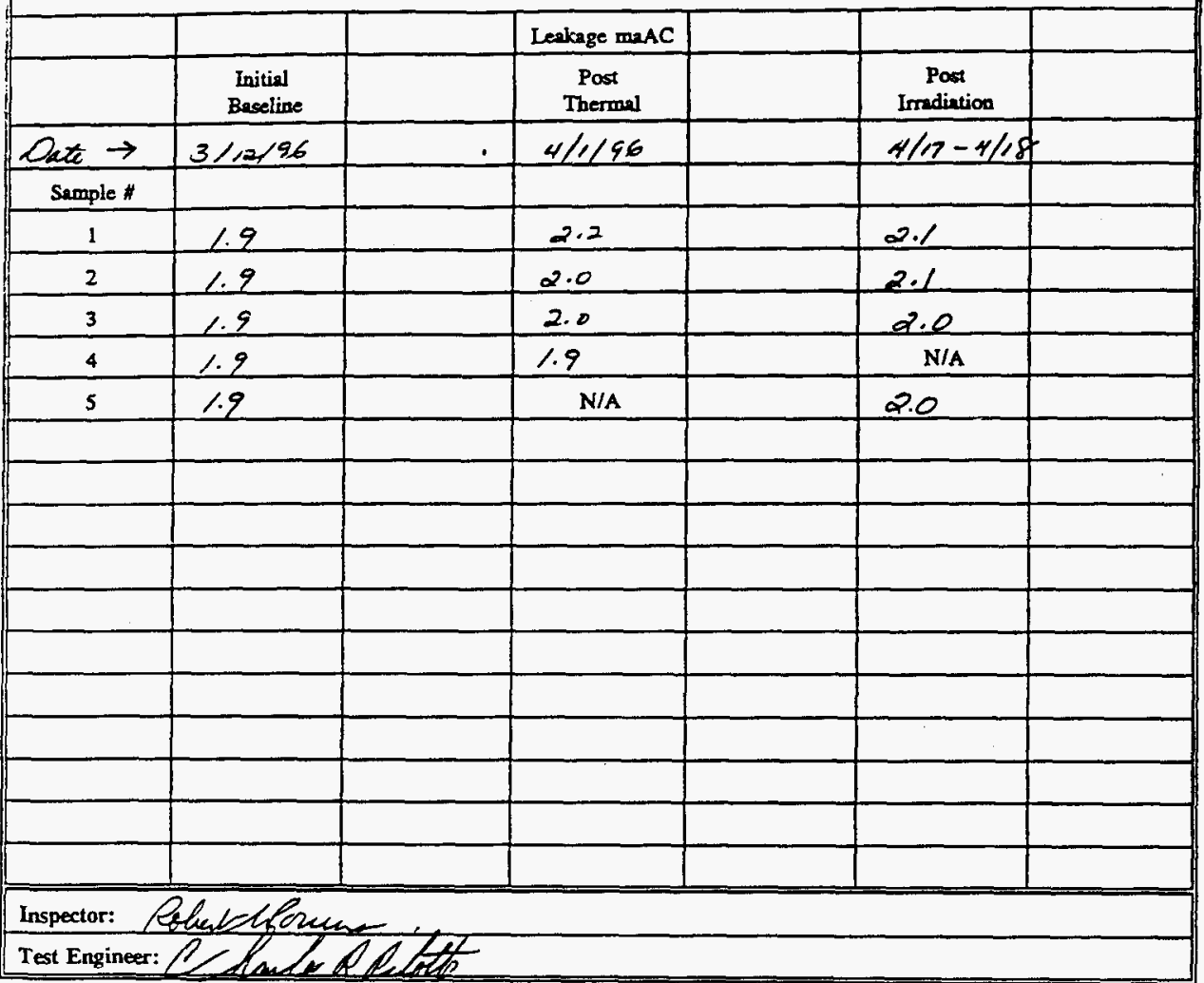

Procedure No. 60776-97N

Revision 0

Pagetivitis 


\section{ALEs}

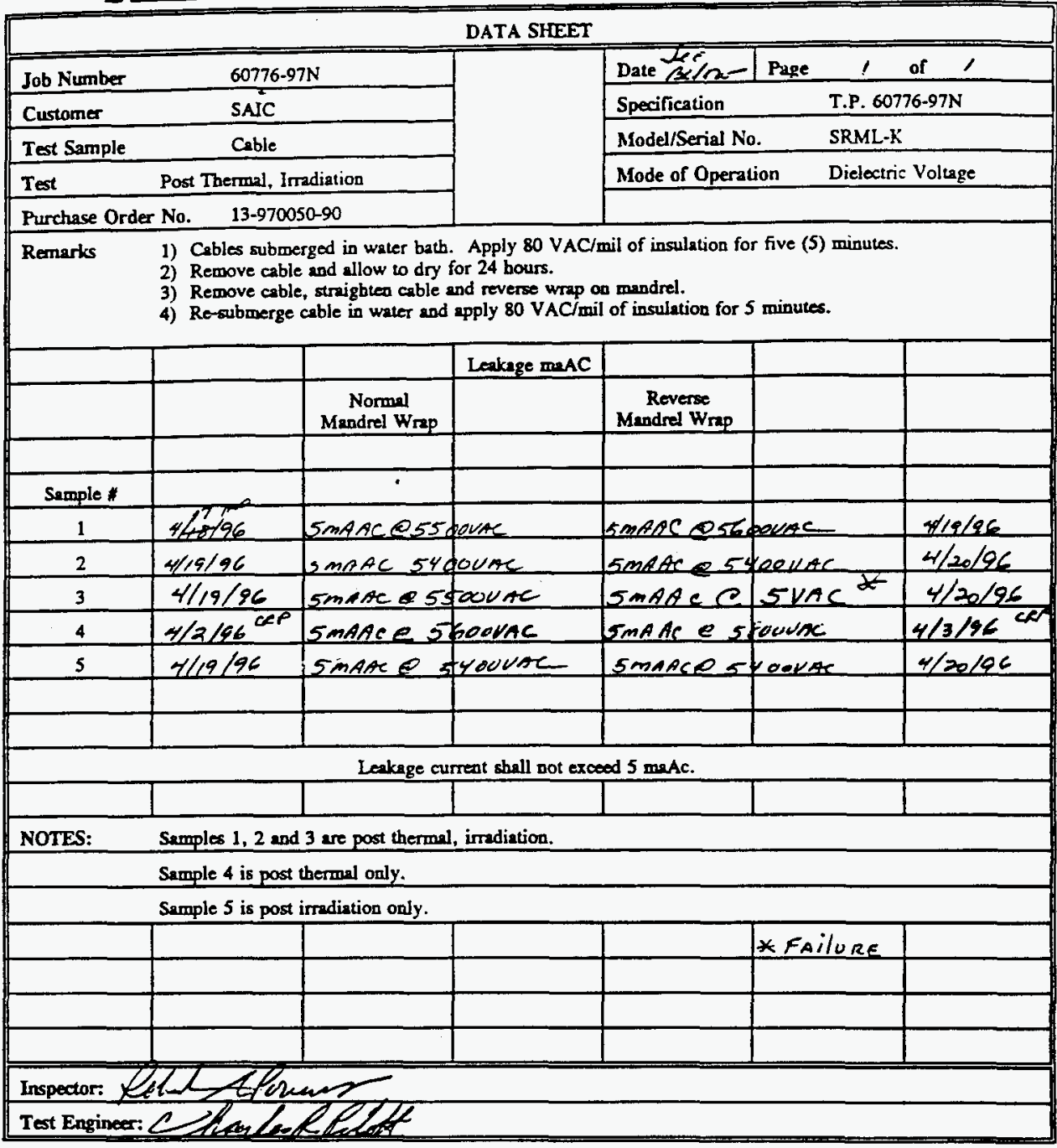


WHC-SD-WM-TI-758, Rev. 0

ares

APPENDIX B

ANALYTICAL REPORT BY SPRINGBORN LABORATORIES

$$
\begin{aligned}
& \text { Report No. 60776-97N } \\
& \text { Revision 0 } \\
& \text { Pagasta-2] } \\
& B-48
\end{aligned}
$$


Project No. 11885.0113

March 20, 1996

$\begin{array}{ll}\text { CLIENT: } & \begin{array}{l}\text { National Technical Systems } \\ 533 \text { Main Street } \\ \text { Acton, MA 01720 }\end{array} \\ \text { ATIENTION: } & \text { Charles Pilotte } \\ \text { AUTHORIZATION: } & \text { Purchase Order No. 50709N }\end{array}$

\section{SAMPLES RECEIVED: (03/06/96) TAACECODE: A96.0081}

Two (2) Samples labeled: K·Fiber Braid and Silicone Rubber

\section{ANALYSIS REQUESTED:}

Activation Energy

\section{RESULTS AND DISCUSSION:}

Thermal analysis was performed on the submitted samples using a DuPont 9000 thermal analyzer equipped with a DuPont 951 TGA. The samples were analyzed from $25^{\circ} \mathrm{C}$ to $710^{\circ} \mathrm{C}$ at 5,10 and $20^{\circ} \mathrm{C} /$ minutes under nitrogen. The data was collected and stored on an Omnitherm Xtra Data Acquisitioner. The activation energy was determined at 5, 10,20 and 50\% weight loss. The results of this analysis are found on the attached table.

Please contact us if you have any questions regarding these results or if you require additional information.
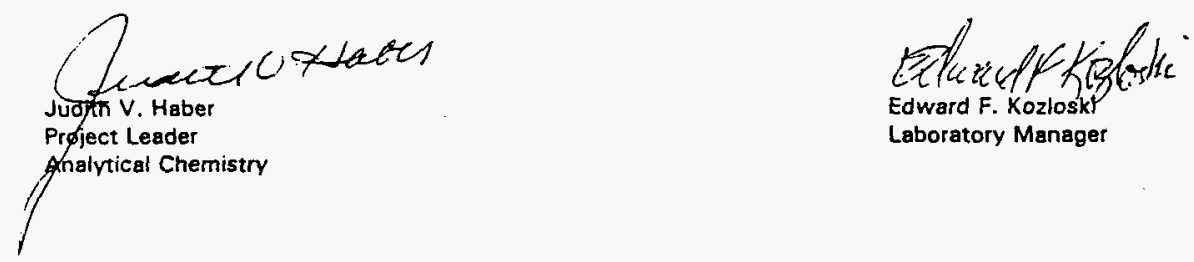

\section{6 \\ $B-49$ \\ ESpringbom}

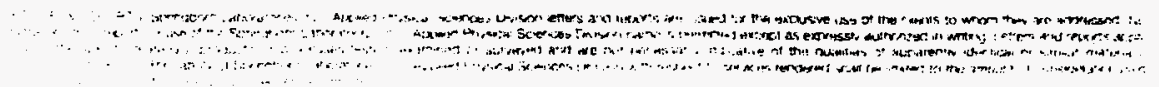


Project No. 11885.0113

March 20, 1996

NTS

Page Two

\begin{tabular}{||c|c|c|c|c|}
\hline \multirow{2}{*}{ Sample } & \multicolumn{4}{|c|}{ AESULTS TABLE } \\
\cline { 2 - 5 } & $5 \%$ Wt Loss & $10 \%$ Wt Loss & $20 \%$ Wt Loss & $50 \%$ Wt Loss \\
\hline K-Fiber Braid & 0.69 & 1.47 & 0.44 & No $50 \%$ loss \\
\hline Silicone Rubber & 1.61 & 1.76 & 1.43 & No $50 \%$ loss \\
\hline
\end{tabular}




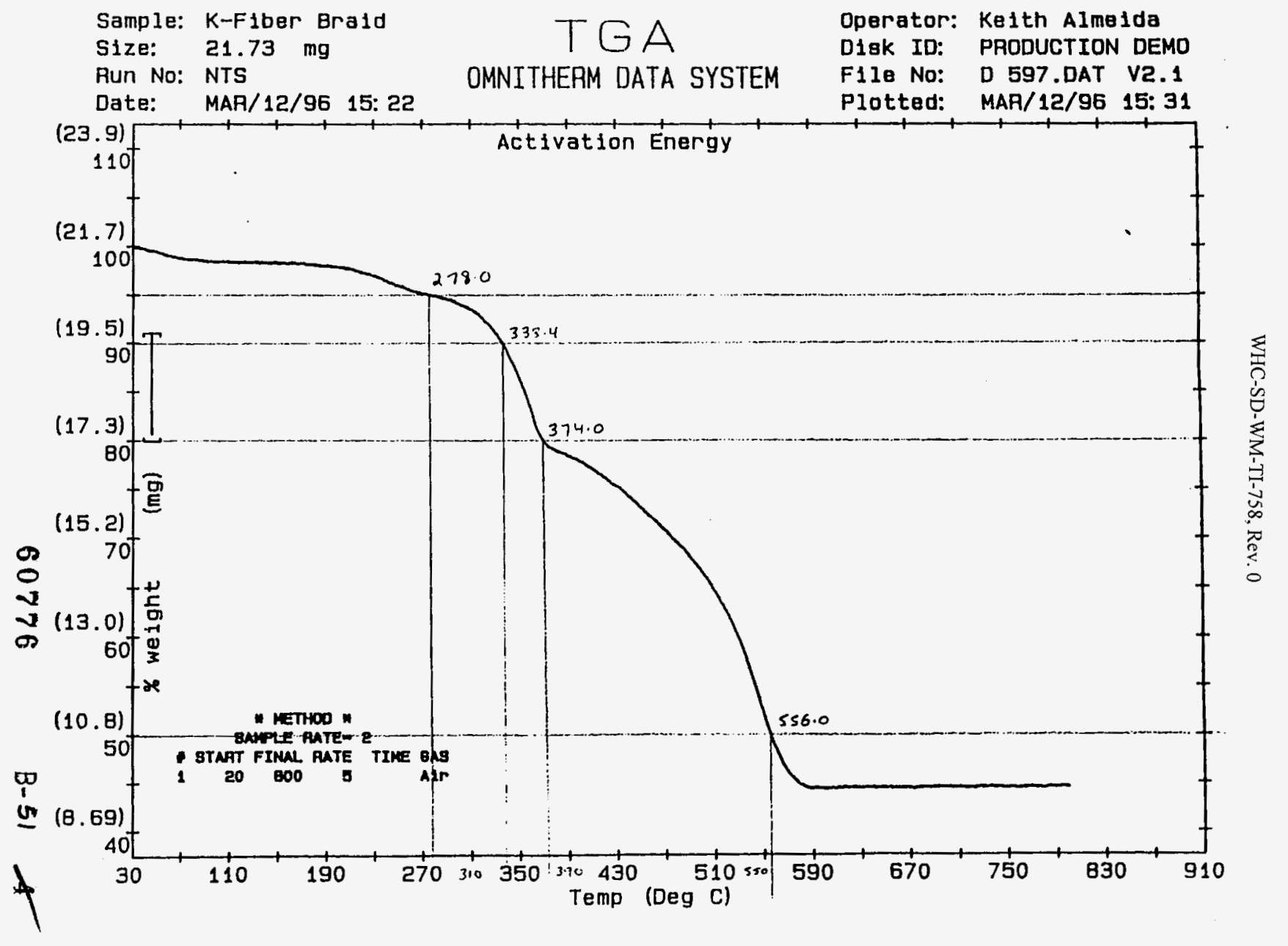




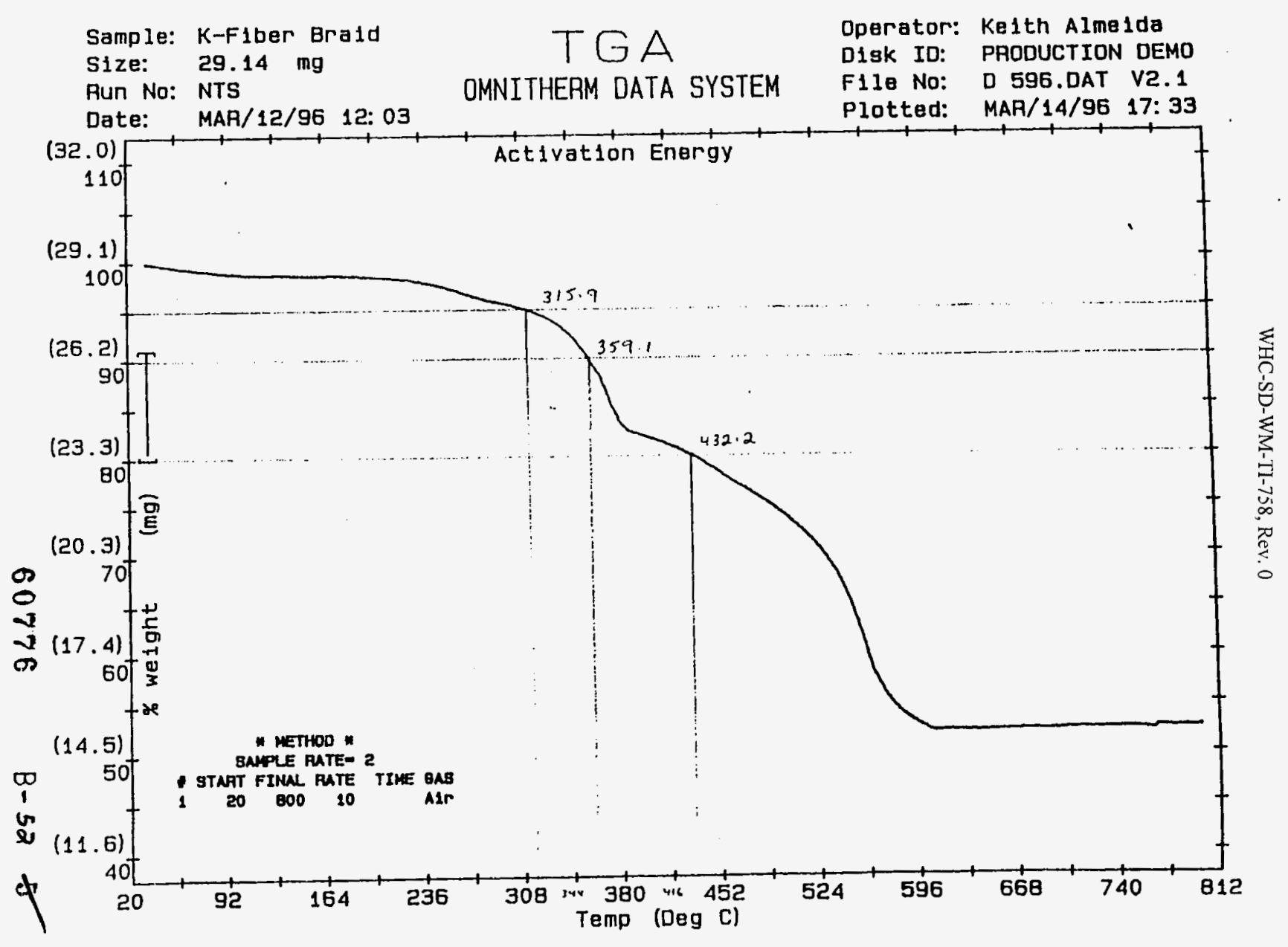




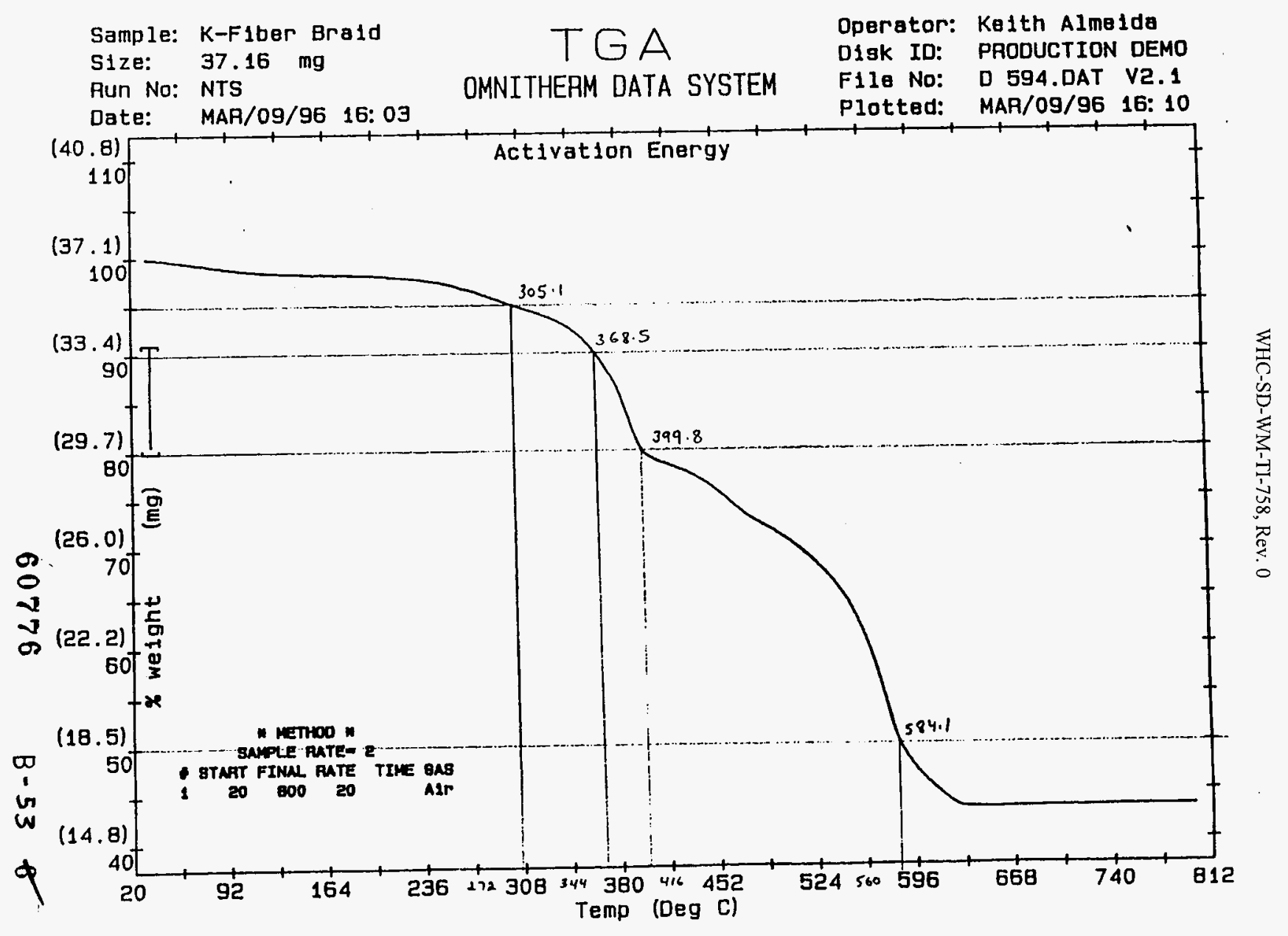




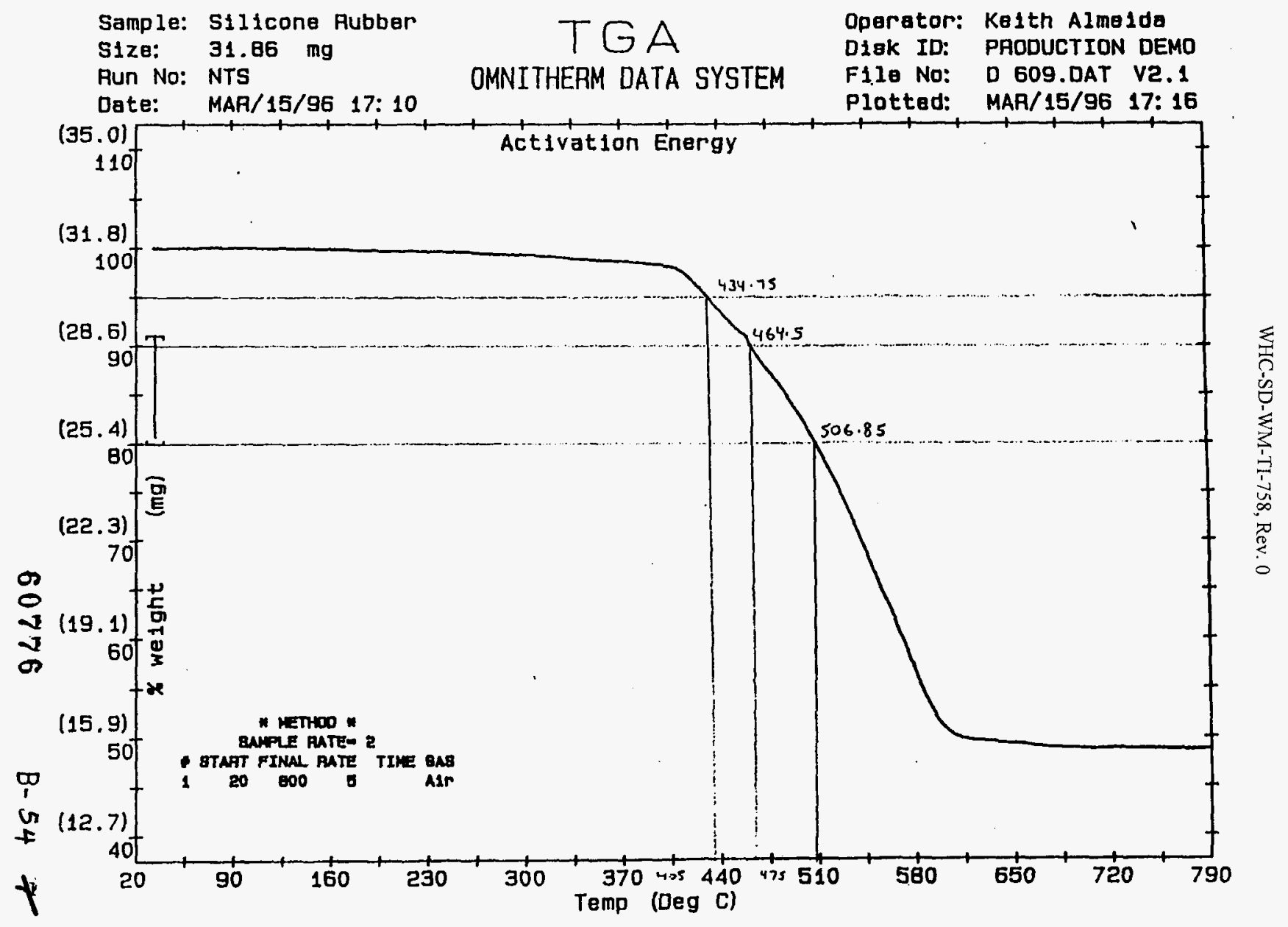




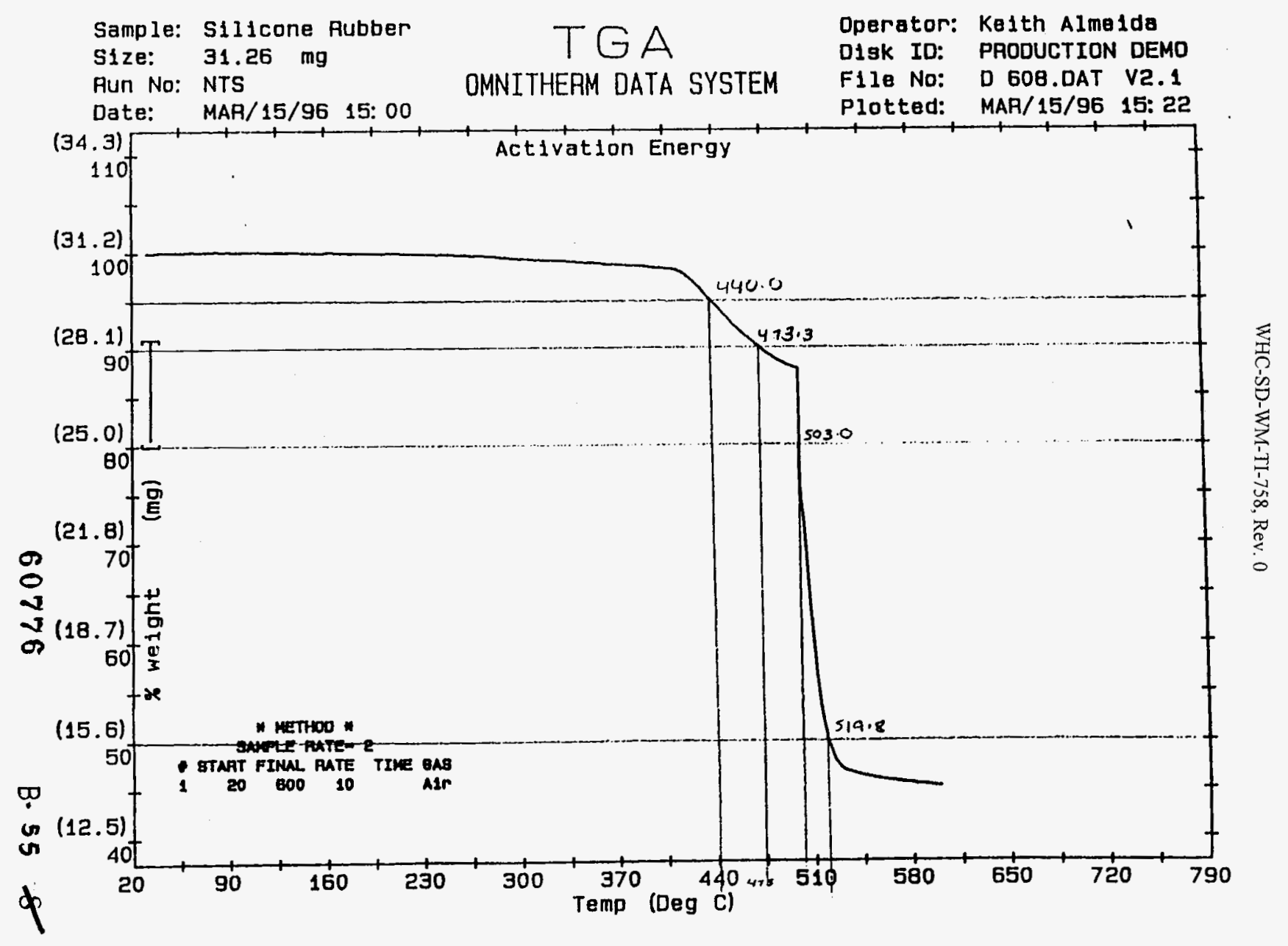




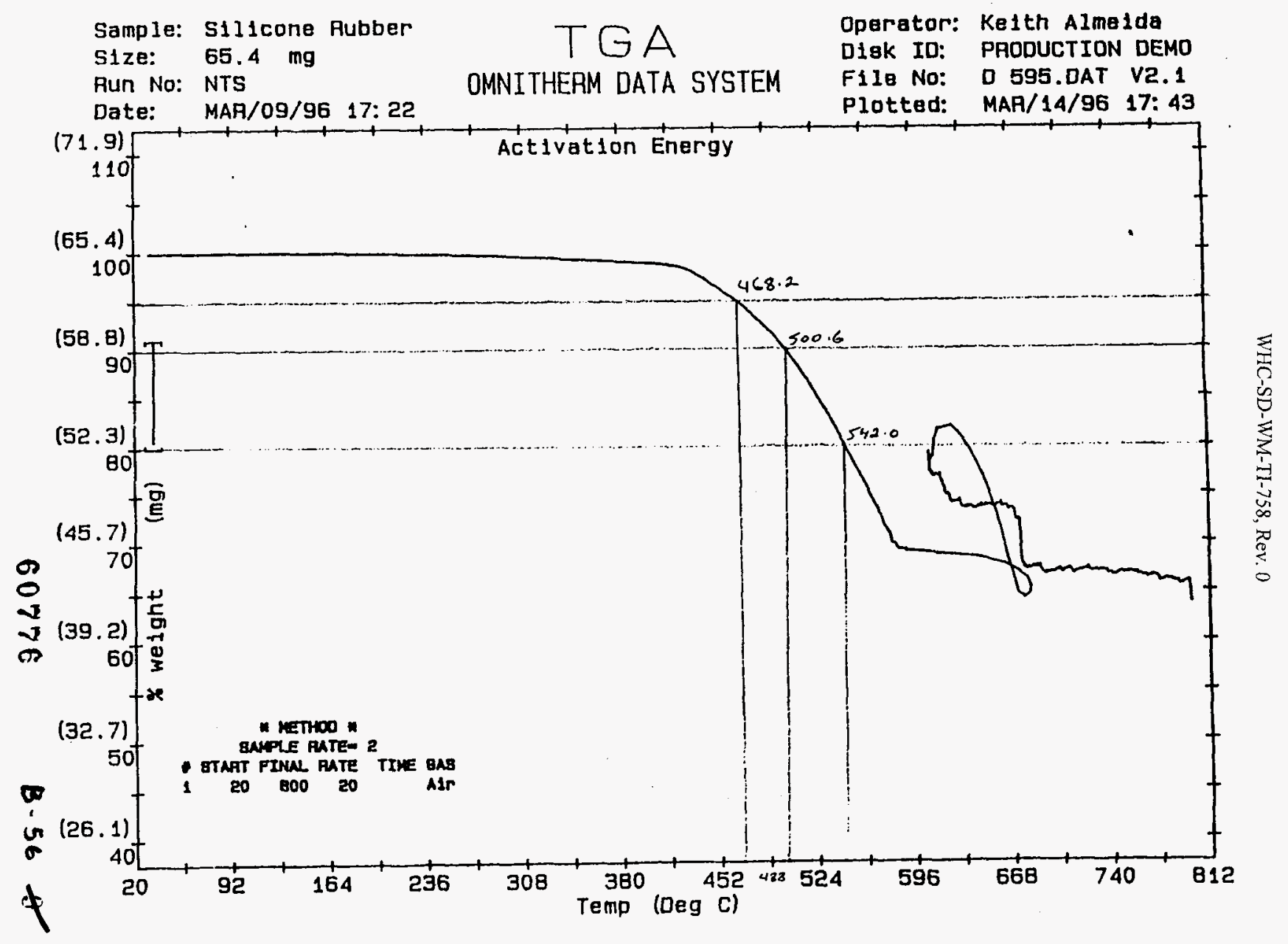


WHC-SD-WM-TI-758, Rev. 0

ATES

\section{APPENDLX C}

THERMAL AGING CHARTS

Report No. 60776-97N Revision 0 
ares

National

Technics

Systems
Northeast Division

533 Main Street

Acton, MA 01720

DATA SHEET

Job Number $60776-97 \mathrm{~N}$ $S A 1 C$

Test Sample Fades Cable.

Test Yhenenal Assize
Date $3 / 13 / 96$

Page 1 of 2

Specification T.P. $60>76-97 \mu$

Model Aerial Number SR MK-T

Mode of Operation. Daily La.

Purchase Order $13-970050-00$

Remarks Samples 1 three y ane plane si even e $230003 / 13 / 96$

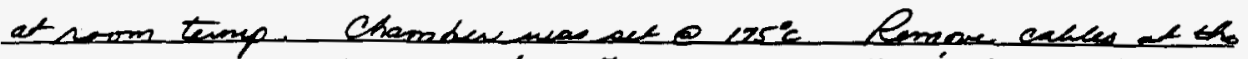

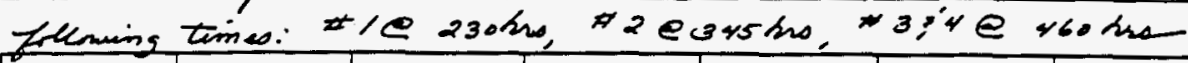

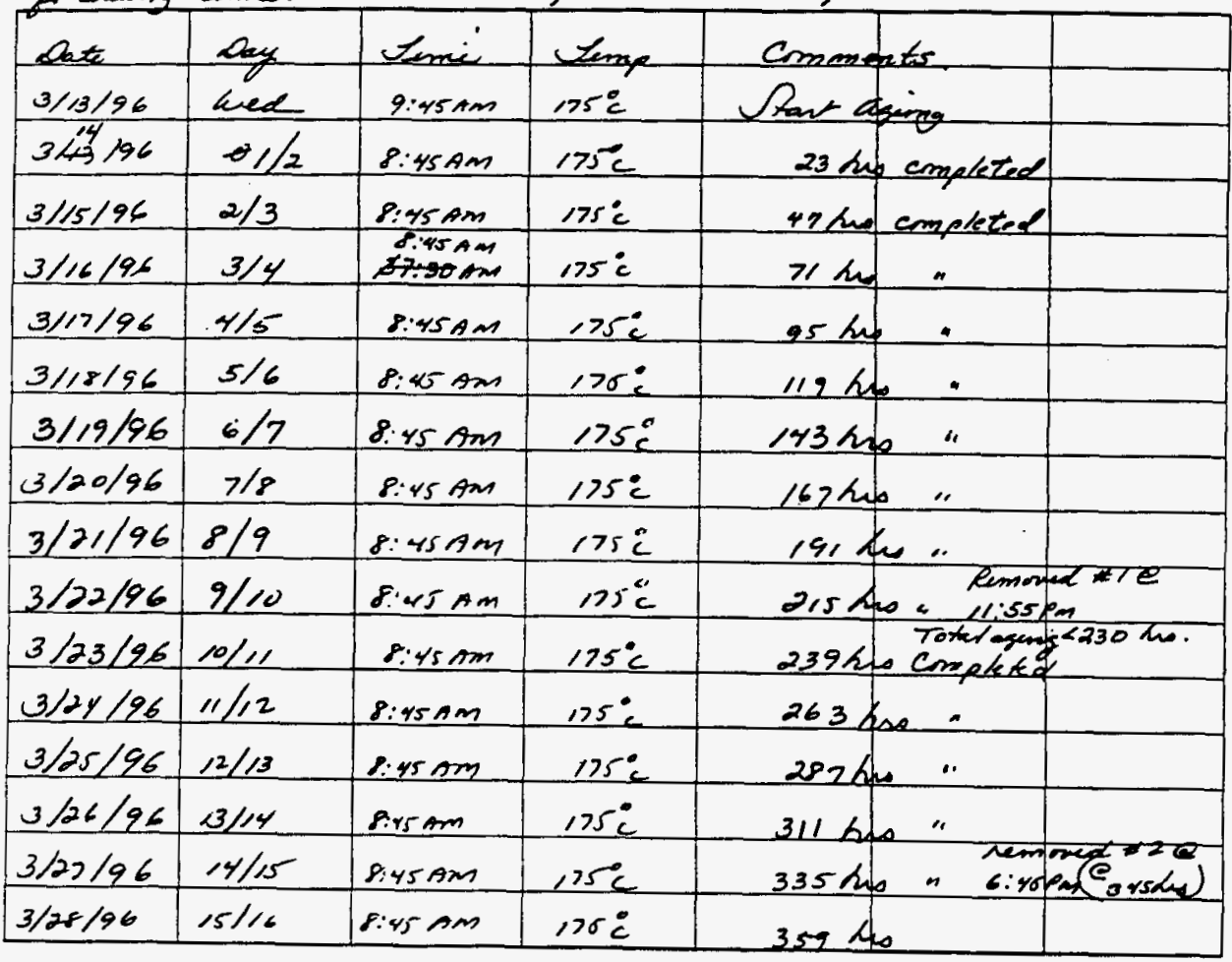

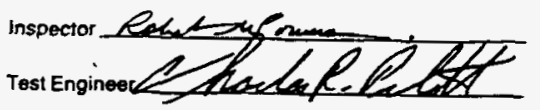

$B-582$

Form 202 
ares

WHC-SD-WM-TI-758, Rev. 0

National

Technical

Systems
Northeast Division

533 Main Stree

Acton, MA 01720

DATA SHEET

Job Number $60776-97 N$

Customer $\triangle A K$

Test Sample Cadi* C- ale

Test Theron Asia

Purchase Order 13-970050-90
Date $3 / 27 / 95$

Page 2 of 2

Specification I.P. $\quad 60>26-97 \mu$

Model/Serial Number $S R \cap L-A$

Mode of Operation Osis/y Log

Remarks

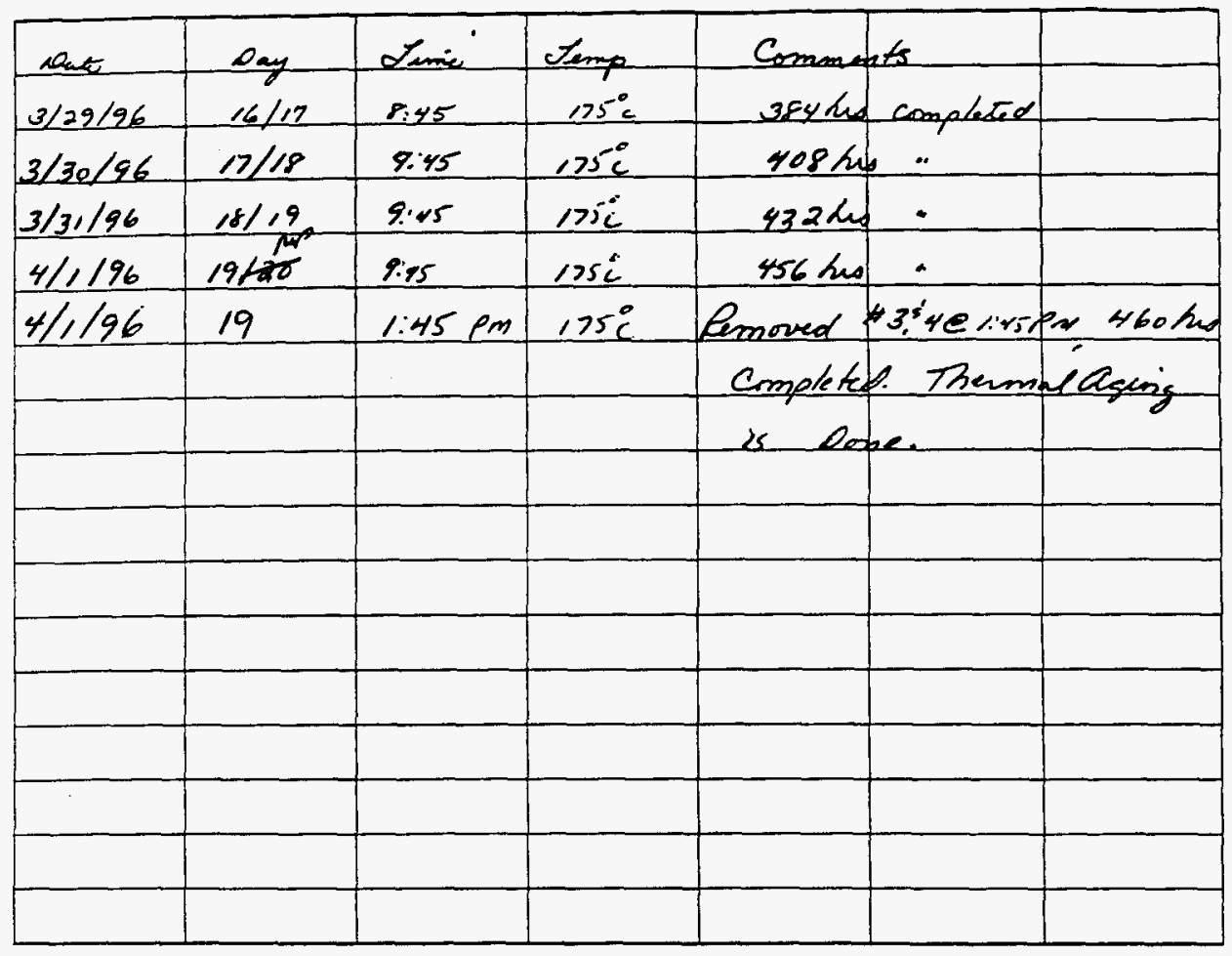

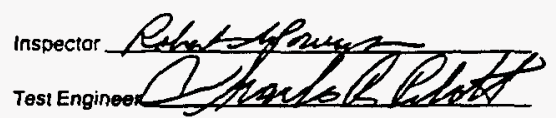

B- 59

Form 20.2 


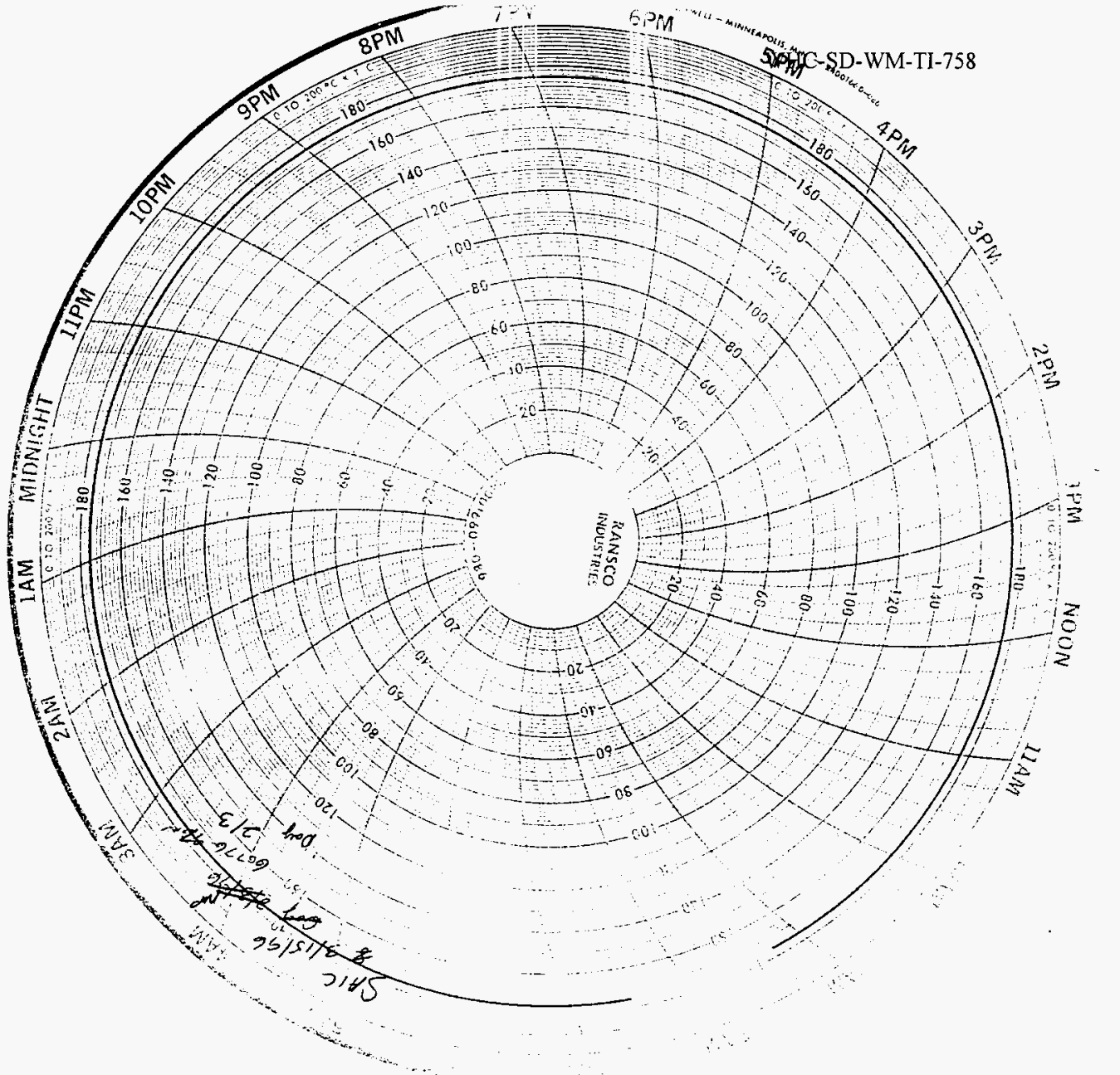

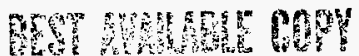




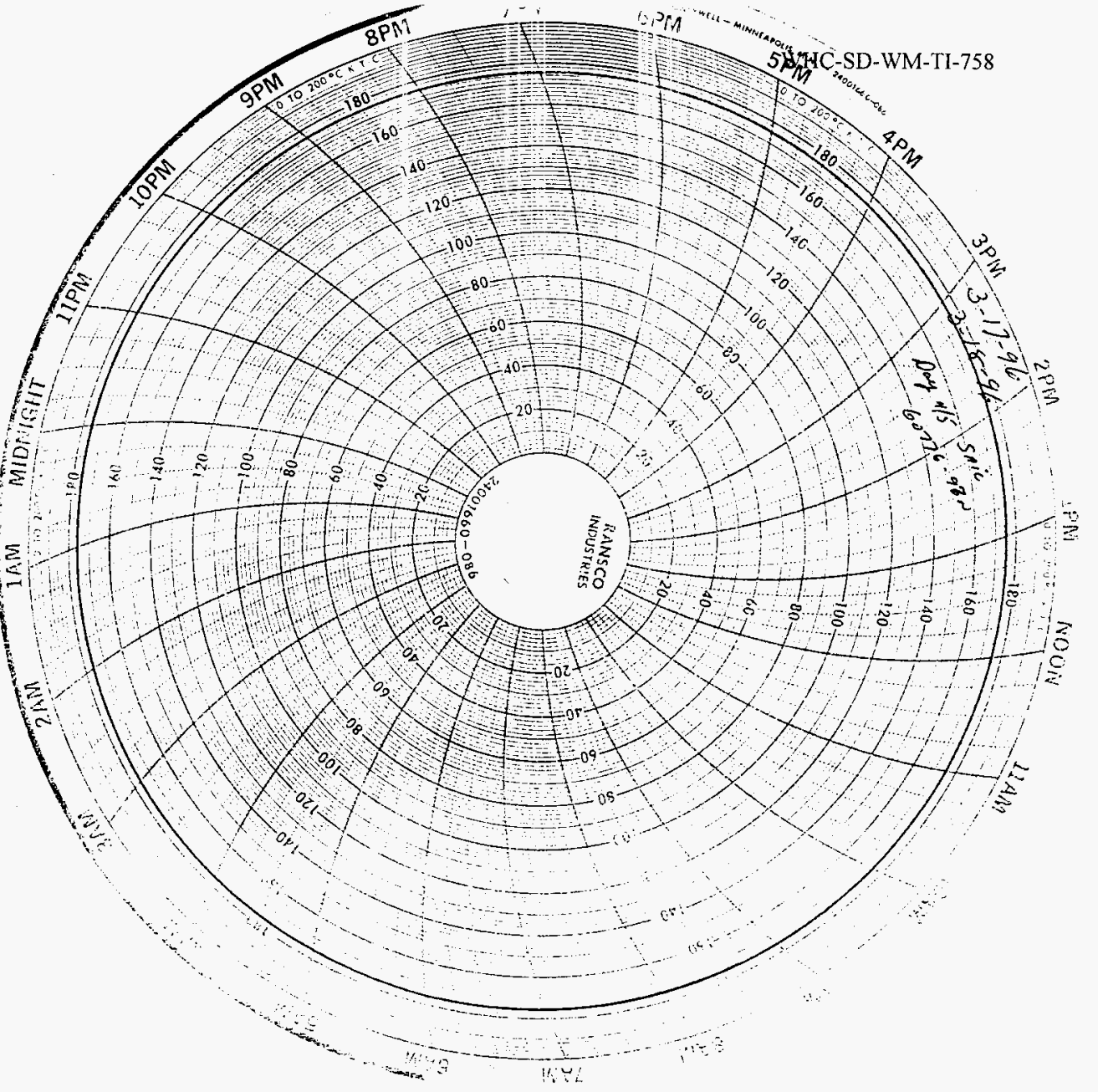

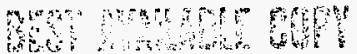






Met rencents 


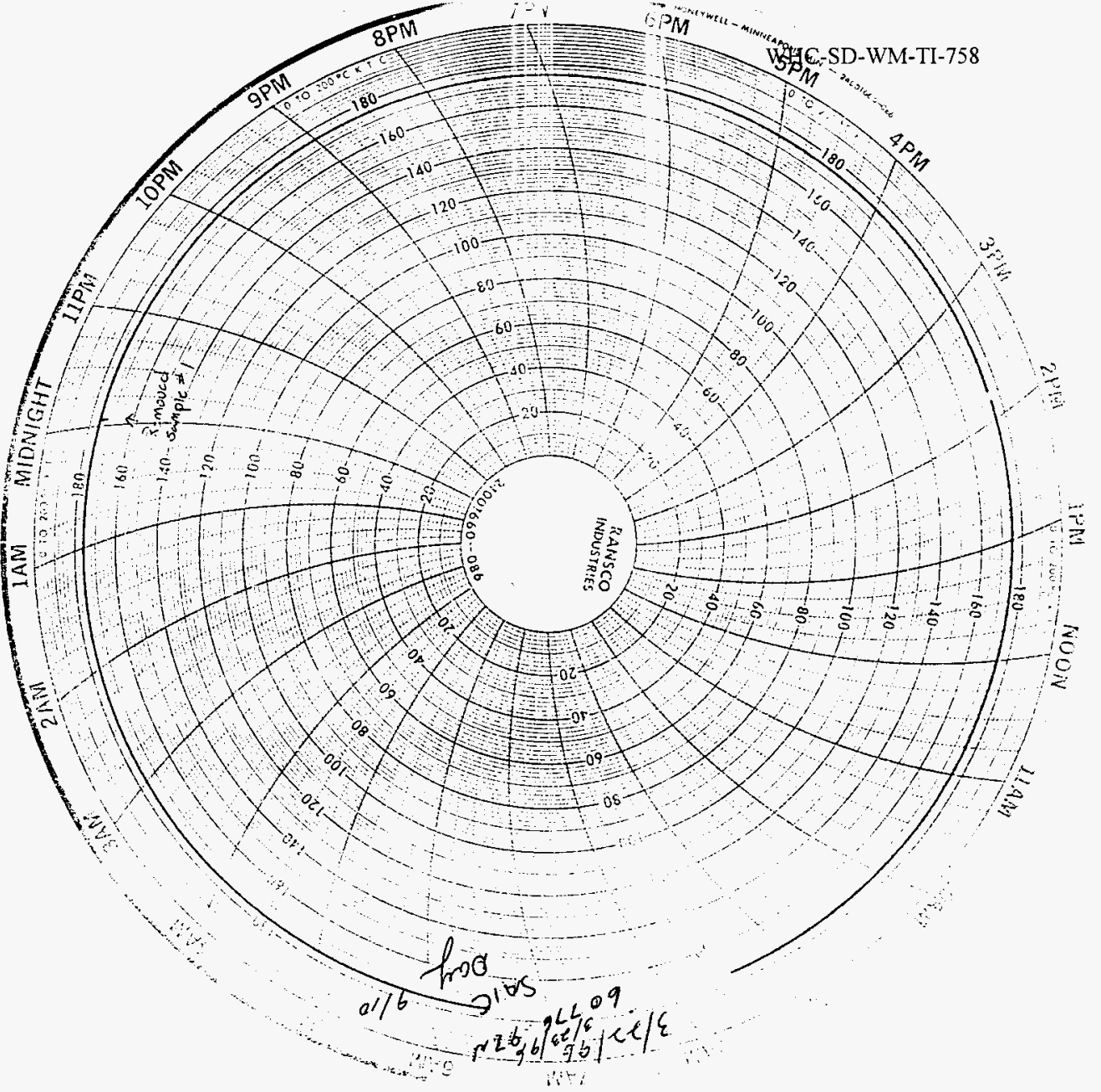

BSTOERP 


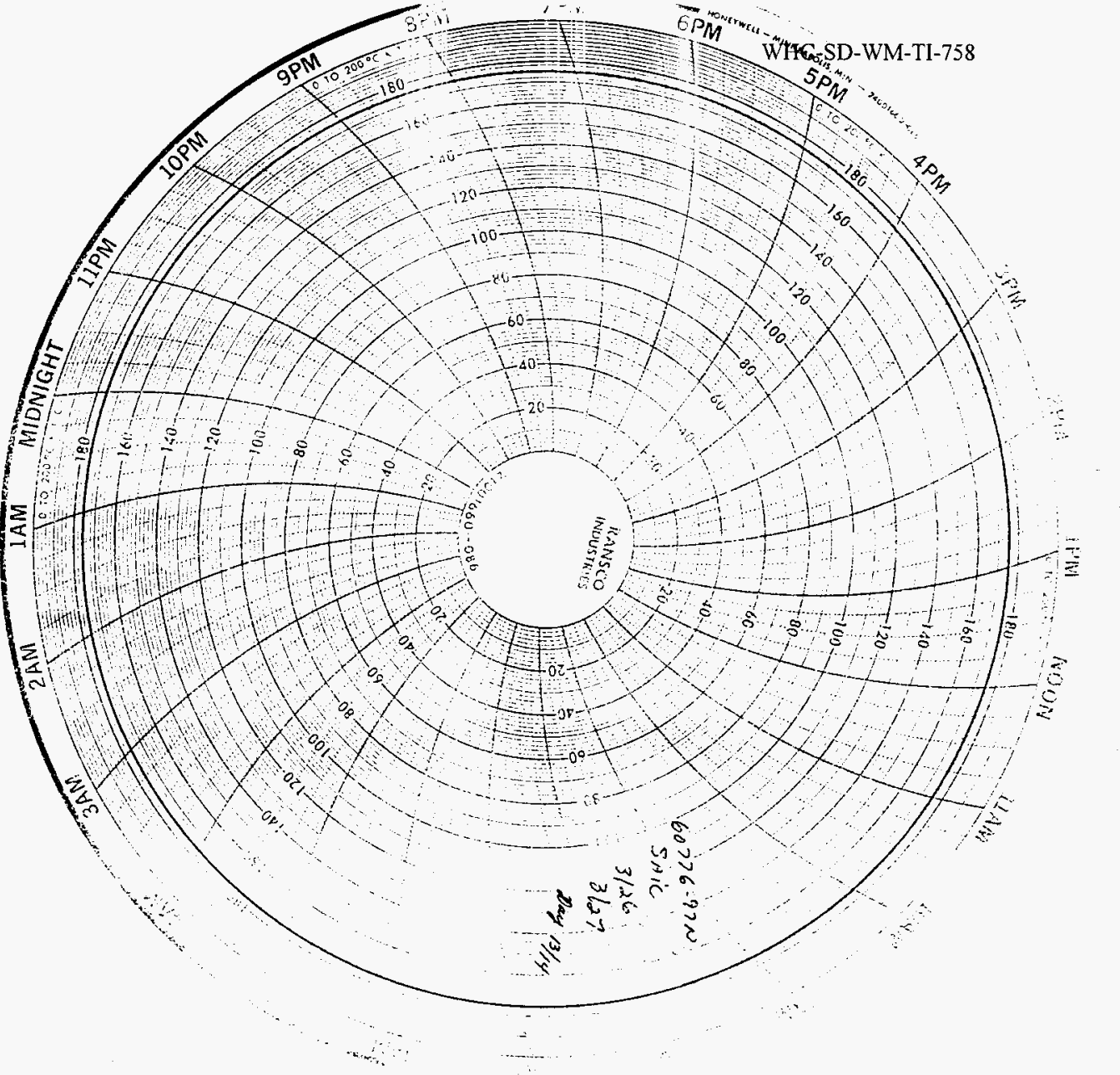

मf rmon 


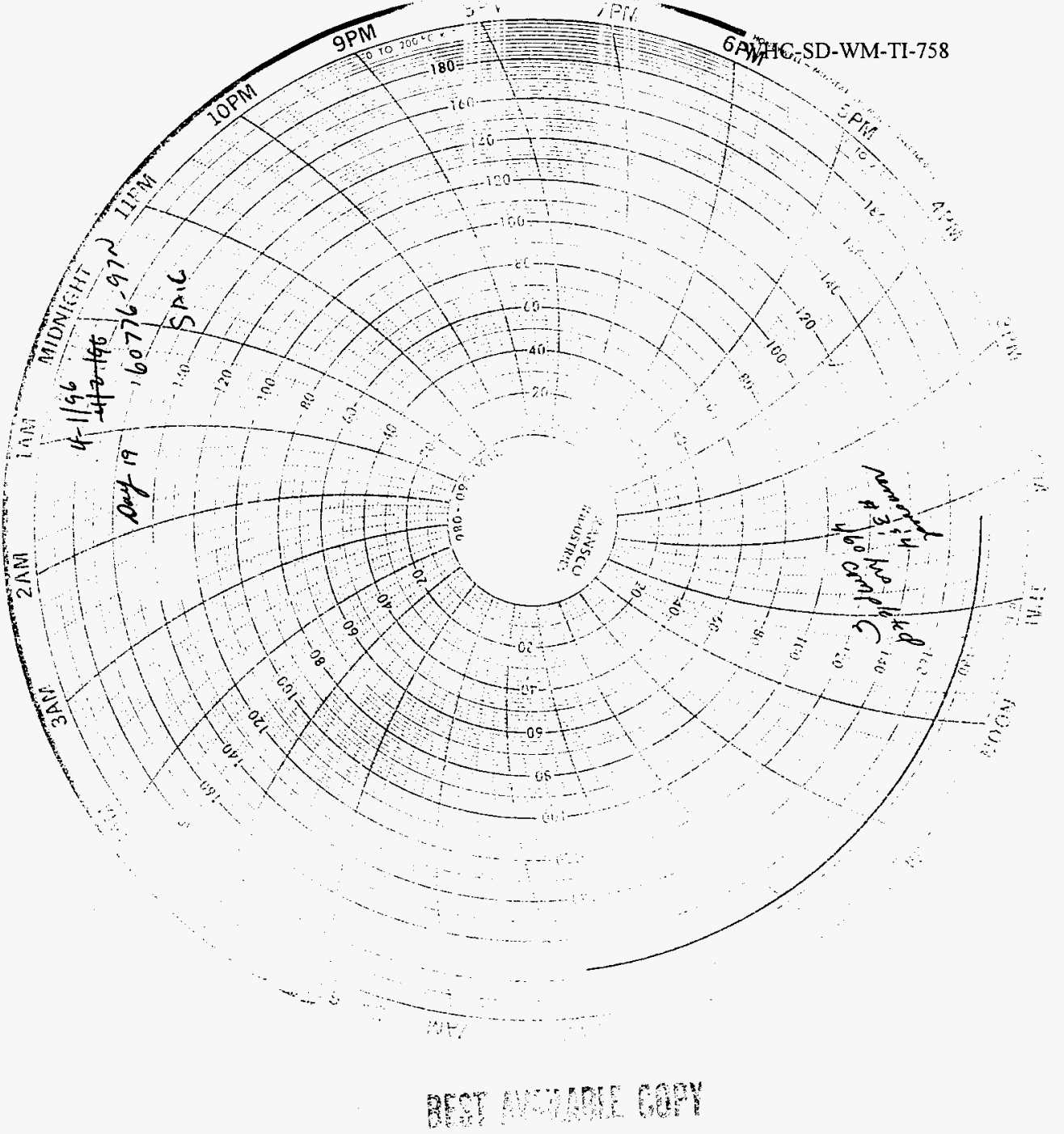


WHC-SD-WM-TI-758

ares

APPENDIX D

ISOMEDIX REPORT

Report No. 60776-97N

Revision 0

Pagolioner $B \cdot 80$ 


\section{ISOMEDIX OFERATIONS \\ 9 AFULLO DRIVE \\ WHC-SD-WM-TI-758 \\ WHIPPANY, N 07981}

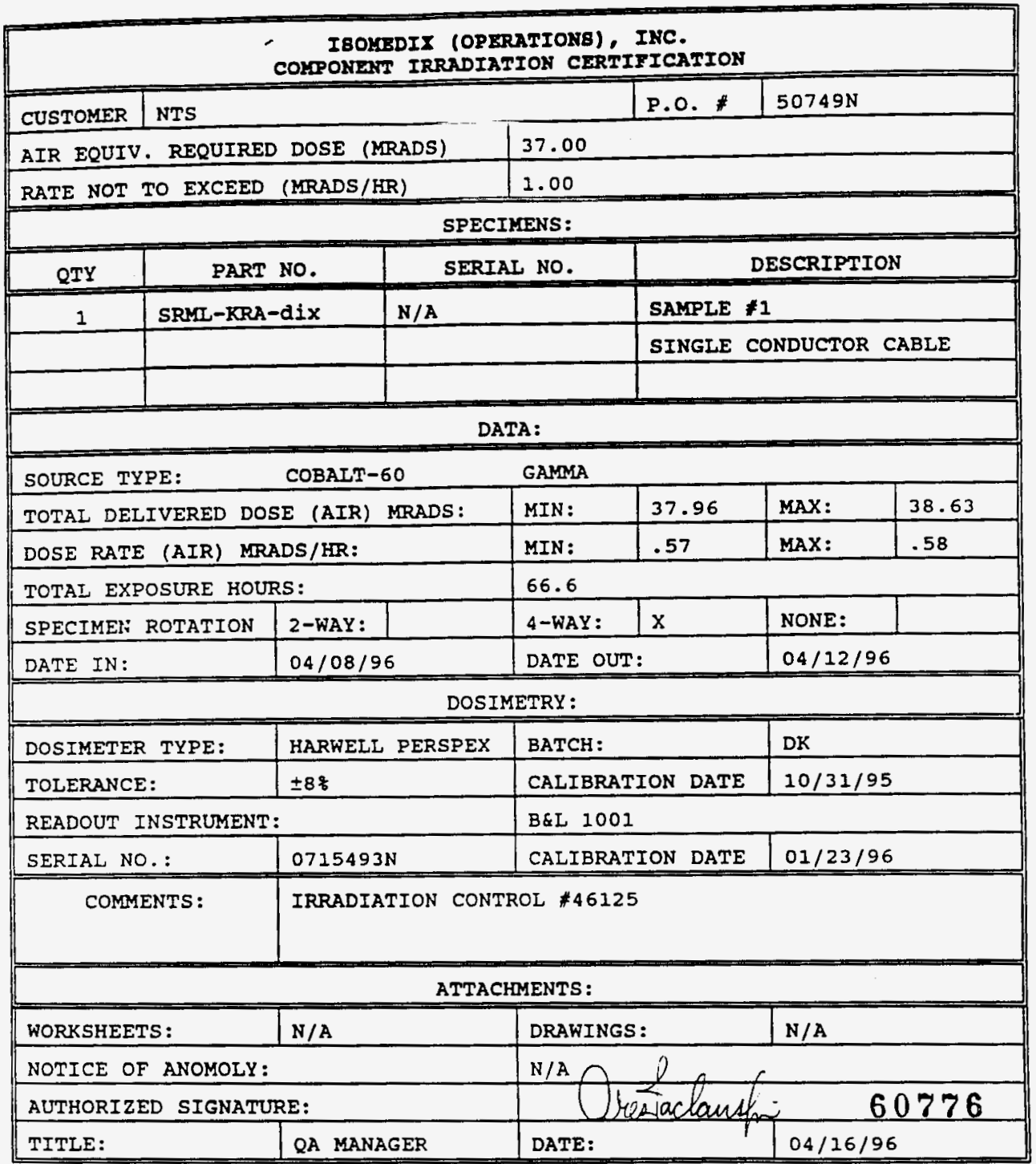

Form 1702.3

original 


\section{ISOMEDIX OPERATIOKS \\ 9 APOLLO DRIVE \\ WHC-SD-WM-TI-758 \\ WHIPPANY, NJ 07981}

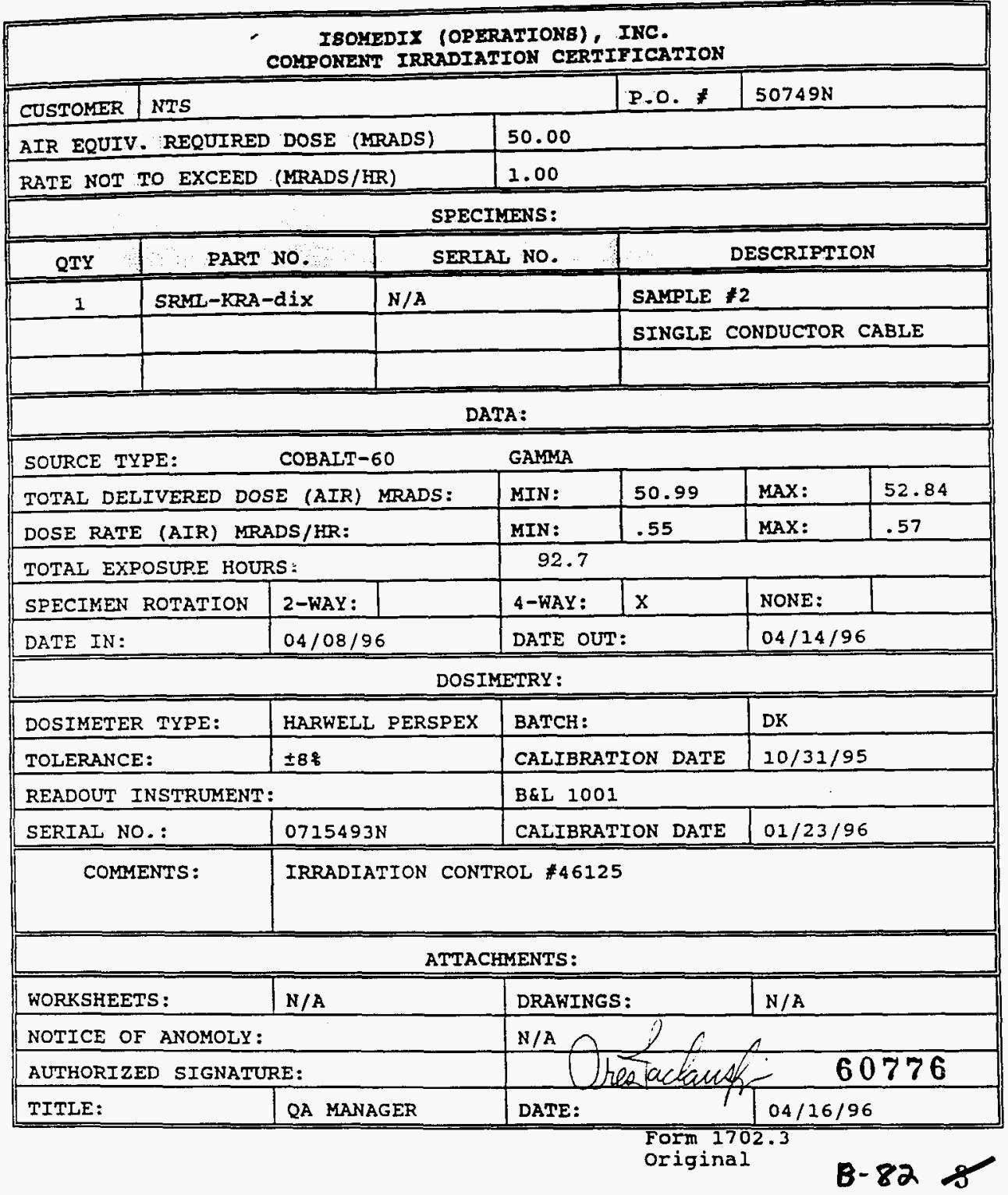




\section{ISOMEDIX OPERATIORS WHC-SD-WM-TI-758 \\ 9 APULLO DRIVE \\ WHIPPANY, NJ 07981}

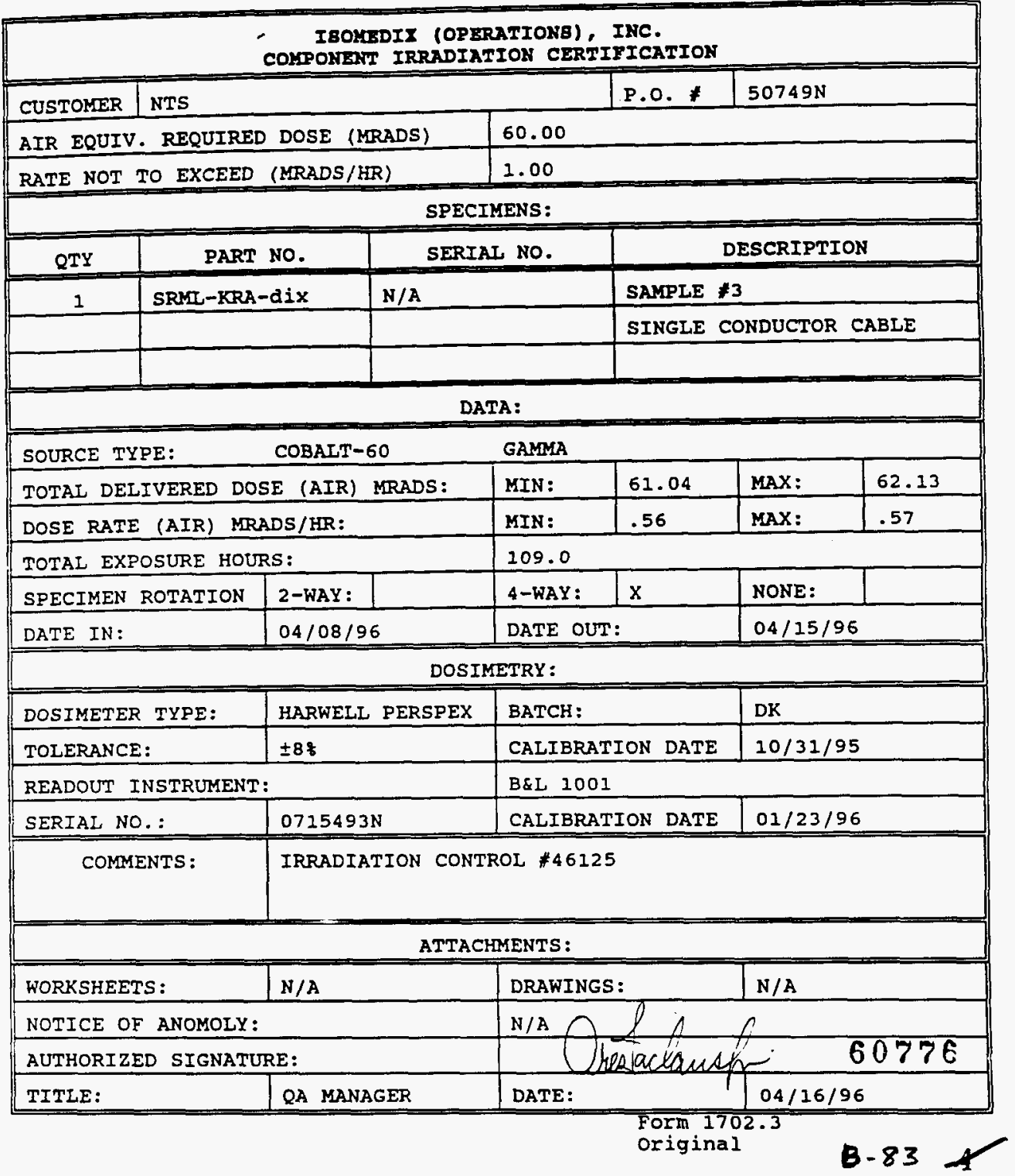




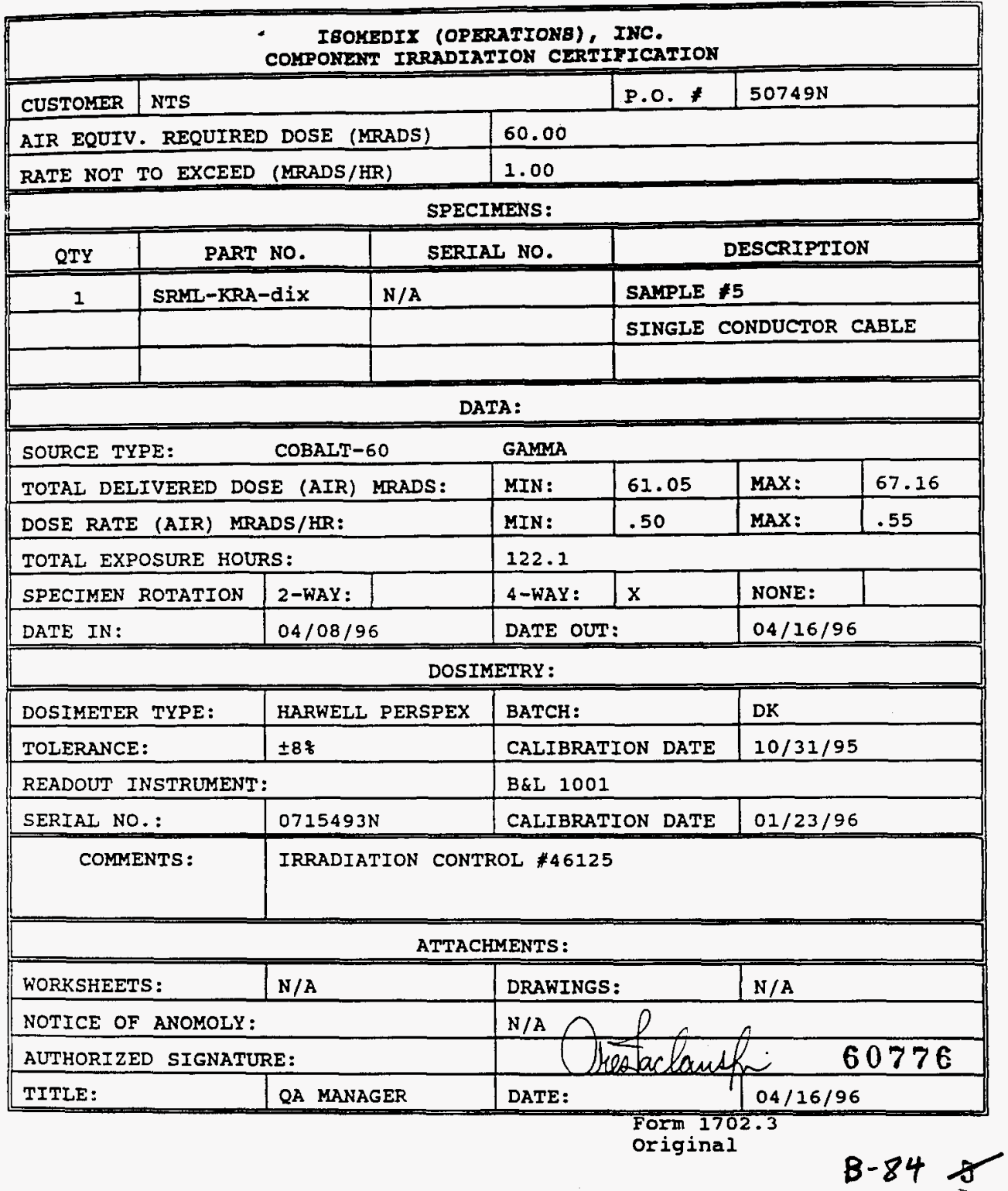




\section{APPENDIX E}

PHOTOGRAPHS

Report No. 60776-97N 
AhEs

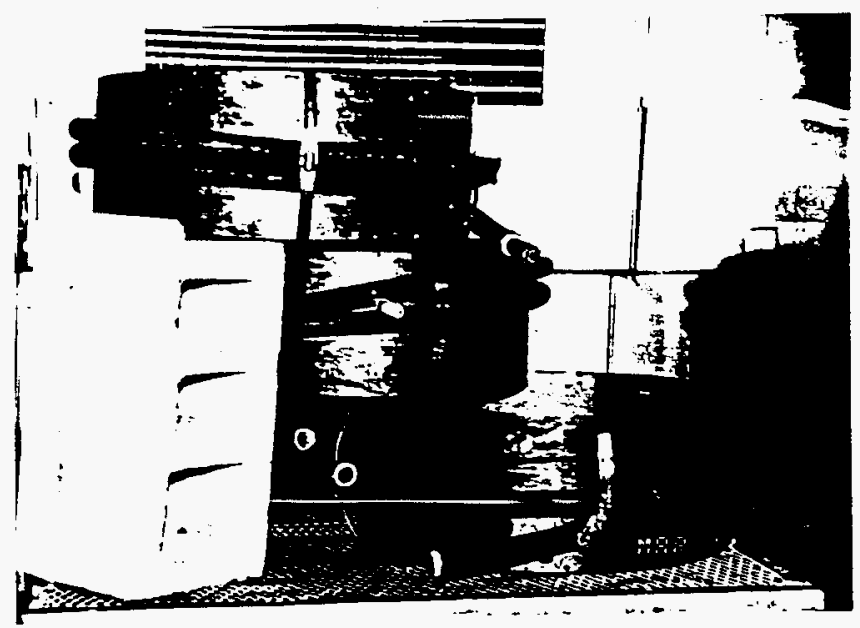

THERMAL AGING, CABLES ON SOLID MANDREIS, SAMPLES $1,2,3$ \& 4

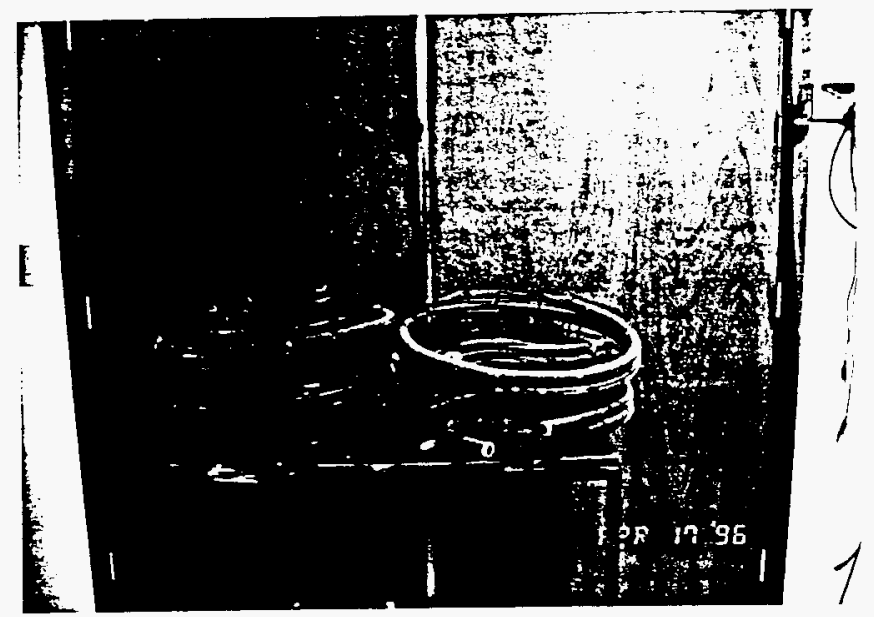

WIRE MESH MANDRELS FOR IRRADIATION, SAMPLES 1, 2, 3 AND 5

Report No. 60776-97N Revision 0

Devo.to? $B-86$ 


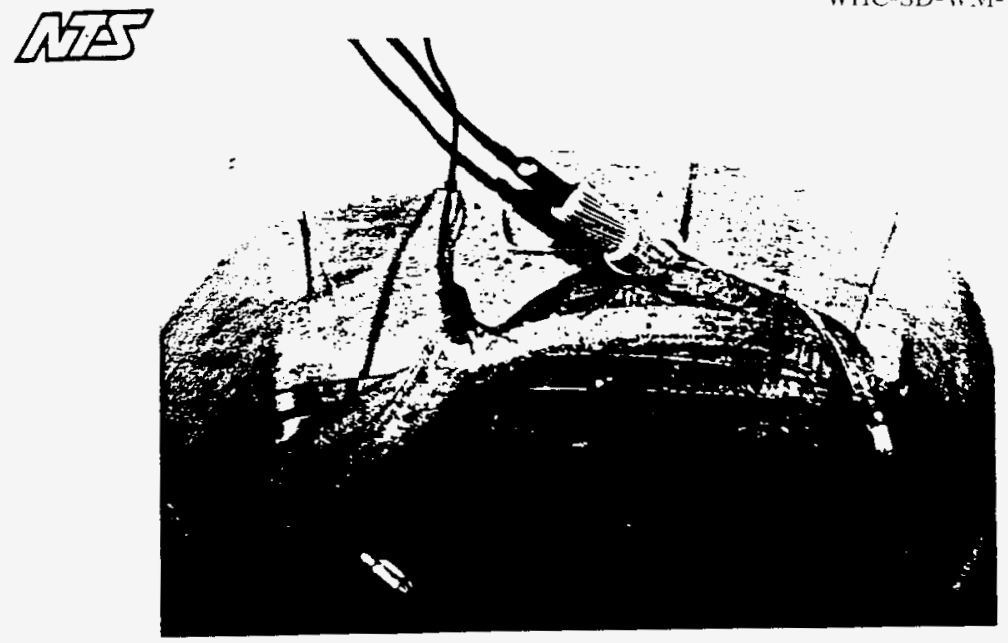

TYPICAL CABLE SUBMERGED IN WATER BATH

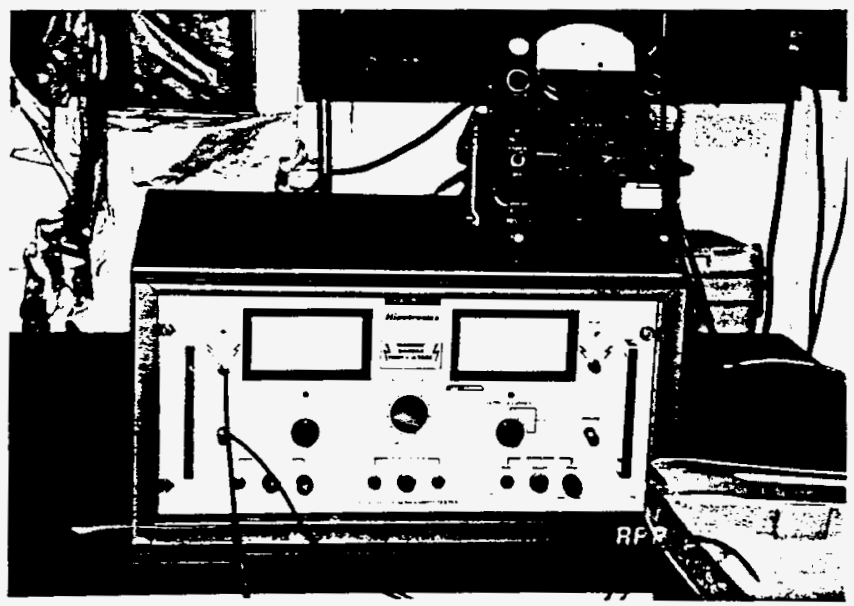

HIGH VOLTAGE TESTER AND IR TESTER

Report No. $00776-97 \mathrm{~N}$

Revision 0

$B-87$ 